\title{
Taxonomic revision of black salamanders of the Aneides flavipunctatus complex (Caudata: Plethodontidae)
}

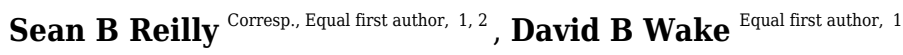 \\ 1 Museum of Vertebrate Zoology and Department of Integrative Biology, University of California, Berkeley, California, United States of America \\ 2 Department of Ecology and Evolutionary Biology, University of California, Santa Cruz, California, United States of America \\ Corresponding Author: Sean B Reilly \\ Email address: sreilly@ucsc.edu
}

We present a taxonomic revision of the black salamander (Aneides flavipunctatus)complex of northwestern California and extreme southeastern Oregon. The revision is based on a number of published works as well as new molecular and morphological data presented herein. The subspecies Aneides flavipunctatus nigerMyers and Maslin 1948 is raised in rank to a full species. It is isolated far to the south of the main range on the San Francisco Peninsula, south and west of San Francisco Bay. Another geographically isolated set of populations occurs well inland in Shasta County, northern CA, mainly in the vicinity of Shasta Lake. It is raised from synonymy and recognized as Aneides iecanus (Cope 1883). The remaining taxa occur mainly along and inland from the coast from the vicinity of the Russian River and Lake Berryessa/Putah Creek, north to the vicinity of the Smith River near the Oregon border and more inland along the Klamath and Trinity Rivers and tributaries into Oregon. The northern segment of this nearly continuous range is named Aneides klamathensis Reilly and Wake 2019. We use molecular data to provide a detailed examination of a narrow contact zone between the northern $A$. klamathensis and the more southern A. flavipunctatus in southern Humboldt County in the vicinity of the Van Duzen and main fork of the Eel rivers. To the south is the remnant of the former species and it takes the name Aneides flavipunctatus (Strauch 1870). It is highly diversified morphologically and genetically and requires additional study. 
1 Taxonomic Revision of Black Salamanders of the Aneides flavipunctatus

2 Complex (Caudata: Plethodontidae)

3

4 SEAN B. REILLY ${ }^{1,2}$, DAVID B. WAKE ${ }^{1}$

5

$6 \quad{ }^{1}$ Museum of Vertebrate Zoology and Department of Integrative Biology, University of

7 California, Berkeley, California, United States of America

8 'Department of Ecology and Evolutionary Biology, University of California, Santa Cruz,

9 California, United States of America

10

11 Corresponding Authors:

12 Sean B. Reilly

13 Email address: sreilly@ucsc.edu

14 David B. Wake

15 Email address: wakelab@berkeley.edu

16

17 Keywords: Amphibians, California, Cryptic species 
18 Abstract

19

20 We present a taxonomic revision of the black salamander (Aneides flavipunctatus) complex of northwestern California and extreme southeastern Oregon. The revision is based on a number of published works as well as new molecular and morphological data presented herein. The subspecies Aneides flavipunctatus niger Myers and Maslin 1948 is raised in rank to a full species. It is isolated far to the south of the main range on the San Francisco Peninsula, south and west of San Francisco Bay. Another geographically isolated set of populations occurs well inland in Shasta County, northern CA, mainly in the vicinity of Shasta Lake. It is raised from synonymy and recognized as Aneides iecanus (Cope 1883). The remaining taxa occur mainly along and inland from the coast from the vicinity of the Russian River and Lake Berryessa/Putah Creek, north to the vicinity of the Smith River near the Oregon border and more inland along the Klamath and Trinity Rivers and tributaries into Oregon. The northern segment of this nearly continuous range is named Aneides klamathensis Reilly and Wake 2019. We use molecular data to provide a detailed examination of a narrow contact zone between the northern A. klamathensis and the more southern A. flavipunctatus in southern Humboldt County in the vicinity of the Van Duzen and main fork of the Eel rivers. To the south is the remnant of the former species and it takes the name Aneides flavipunctatus (Strauch 1870). It is highly diversified morphologically and genetically and requires additional study.

\section{Introduction}

The black salamander, Aneides flavipunctatus, occurs in the coastal forests and mountains of northwestern California and extreme southwestern Oregon. In recent decades the extent of the geographic range has been refined and extended due to survey work, especially in the northern extent of the range in Oregon (Olson, 2008; Reilly et al., 2013). It has long been recognized that this species contains striking regional variation in color pattern (Fig. 1) and microhabitat preference (Lowe, 1950; Lynch, 1981), and since the advent of molecular genetics a number of studies have attempted to use genetic variation to understand and explain this eco-morphological variation (Larson, 1980; Rissler \& Apodaca, 2007; Reilly et al., 2012; Reilly et al., 2013; Reilly \& Wake, 2015). While many researchers familiar with the species suggested that Aneides 
49 flavipunctatus is a multispecies complex, the mosaic of genetic, ecological, and morphological

50 patterns across its geographic range raises questions concerning diagnosability and boundaries of 51 putative species.

52 The types of Aneides flavipunctatus (Strauch, 1870) were collected by the Russian

53 biologist I. G. Voznesenskii, most likely in 1841 (see below). The listed type locality is

54 “Californien (Neu-Albion)" (Strauch, 1870). New Albion (English version) was a general term

55 for that part of coastal California north of San Francisco Bay that was unoccupied by Mexico,

56 where the Russian colony at Fort Ross had been founded in 1812.

Cope (1883) found a single subadult salamander from the vicinity of the federal fish

hatchery on the McCloud River (close to its juncture with the Pit River, currently under the water of Lake Shasta), in present-day Shasta County, California, and named it Plethodon iecanus. Once he had seen an adult Cope (1886) recognized that his taxon was a relative of Aneides lugubris (Hallowell, 1849) and Aneides ferreus Cope 1869. However, he did not know $P$.

62 flavipunctatus and in his monograph of North American Batrachia (present-day Amphibia)

63 (Cope, 1889) left that taxon in Plethodon, where it remained until Storer (1925) recognized it as an Aneides and reduced A. iecanus to its synonymy. The most recently named member of what we here consider the Aneides flavipunctatus complex is Aneides flavipunctatus niger Myers \& Maslin 1948, a taxon based on populations from the Santa Cruz Mountains on the southern San Francisco Peninsula that has distinctive solid black coloration in adults, with almost no white spotting. The disjunct distribution is well to the south of the rest of the range of the complex. Populations north of San Francisco Bay (including those from inland Shasta County) were all considered to be A.f. flavipunctatus (Myers \& Maslin, 1948). Shortly afterwards, an unpublished Ph.D. dissertation by Lowe (1950) recognized five subspecies within the complex based on color pattern and microhabitat preference: A.f. niger from the Santa Cruz Mountains, A. f. iecanus from Shasta County, A. f. "sequoiensis” from the Klamath Mountains south to northern Mendocino County near Laytonville, $A$. $f$. "quercetorum” from inland areas south of Laytonville, and A.f. flavipunctatus from coastal areas south of Laytonville. Despite not being formally published, meaning that his new names lacked validity, Lowe's dissertation was influential and suggested some of the morphological and ecological variation present within the species. Furthermore, it identified a region in central Mendocino County where multiple ecomorphs were thought to be parapatrically distributed. 
81 the complex experienced a nearly simultaneous distributional fragmentation throughout its range

82 during the Pleistocene. However, some populations (notably those on the southern San

83 Francisco Peninsula and in inland Shasta County) were well differentiated from each other and

84 from populations in the main body of the range. Around this same time a detailed field and lab

85

86

87

88

89

90

91

92

93

94

95

96

97 study of geographic variation throughout the range of the entire complex by Lynch (1981) found, as in Lowe's (1950) more limited study, significant geographic variation in morphology and color pattern. Although many populations had discrete, densely pigmented iridophores, Lynch found that all aspects of coloration in A. flavipunctatus showed ontogenetic variation. Across the range juveniles displayed brassy pigmentation caused by embedded iridophores overlain by xanthophore pigments. Lynch hypothesized that $A$. flavipunctatus was formerly more widespread and morphologically uniform, but that their range became fragmented due to climatic fluctuations, and that isolated populations began to simultaneously differentiate in response to local environmental conditions as a result of the high topographic and climatic diversity in northwestern California. This process ultimately increased the genetic, morphological, and ecological diversity within A. flavipunctatus, leading to divergent lineages that now exhibit highly variable rates and directions of ontogenetic-based morphological evolution (Lynch, 1981). Lynch recommended that a single species, be recognized, with no subspecies.

More recent work documented molecular diversification (mitochondrial (mt) DNA sequence data) (Rissler \& Apodaca, 2007), and sampling of genes (nuclear DNA sequence data) and localities expanded greatly (Reilly et al., 2012, 2013; Reilly \& Wake, 2015). DNA sequence data for 2 mtDNA loci from 18 localities (42 samples) were presented by Rissler \& Apodaca (2007), who identified four major mitochondrial clades (identified as Central, Northwest, Shasta and Southern Disjunct). The sampling was relatively sparse and did not permit identification of boundaries between clades or determination of the degree of genetic isolation of those clades. Using rough range estimates from their mtDNA phylogeny, Rissler \& Apodaca conducted an ecological niche analysis and a contact zone suitability test, finding that each clade contained distinct, yet overlapping, niches. The limited sampling forced the authors to assume the clade designation for many hundreds of locality records using rough geographic criteria. For example, the predicted contact zone for their Central and Northwest clades (corresponding to the Central Core and Northwest clades, respectively, of Reilly \& Wake, 2015; i.e. the taxa A. flavipunctatus 
111 and $A$. klamathensis, respectively, of this study) was approximately $40 \mathrm{~km}$ south of the actual

112 contact zone. Their suitability analysis found their proposed contact zone to be unsuitable for the

113 Central clade, but suitable for the Northwest clade (which in fact ends well to the north). While

114 these types of niche models and contact zone analyses can provide insights into ecologically

115 driven lineage divergence, such studies are only as reliable as the lineage boundaries, which

116 requires accurate assignment of an adequate number of populations.

117 Rissler \& Apodaca (2007) made no formal taxonomic changes, but they did recommend a

118 four species taxonomy. The ill-defined boundary between the Central and Northwest clades $(A$.

119 flavipunctatus and A. klamathensis sp. nov.) and the level of reproductive isolation between them

120 were resolved by Reilly \& Wake (2015), who sequenced $3 \mathrm{mtDNA}$ loci for 240 samples from

121136 localities, along with 13 nDNA loci for 145 samples from 93 localities. Reilly \& Wake

122 (2015) confirmed the existence of four major genetic lineages within the complex, and within the

123 contiguous main range a boundary between northern and southern taxa lies along and just south

124 of the Van Duzen River and tributaries in southern Humboldt County, CA. Gene flow estimates

125 across this contact zone were both well below the $2 \mathrm{Nm}$ value of 1 , suggesting that there has not

126 been sufficient gene exchange to prevent species divergence.

127 In this study we 1) compile the findings of all previous work on Aneides flavipunctatus,

128 2) provide new genetic data that better defines the Humboldt County contact zone, 3) utilize

129 morphometric data to distinguish putative species, and 4) formally recognize four distinct

130 species-level taxa within the complex. The geographically disjunct subspecies Aneides

131 flavipunctatus niger Myers and Maslin 1948 is elevated to Aneides niger, Plethodon iecanus

132 (Cope 1883) is recognized as Aneides iecanus, a new taxon represented by populations north of

133 the Van Duzen River region (see below and Reilly \& Wake, 2015 for a full range description) is

134 named Aneides klamathensis, and populations in the coast ranges south of the Van Duzen River

135 region to Sonoma and Napa Counties (originally Plethodon flavipunctatus (Strauch 1870)) retain

136 the name Aneides flavipunctatus. Highly divergent lineages remain within the revised Aneides

137 flavipunctatus, and we suggest that next-generation sequencing along with dense sampling will

138 be needed to determine the number of independently evolving lineages.

139

140 Materials and Methods

141

Peer] reviewing PDF | (2019:04:36410:1:1:NEW 22 Jun 2019) 
142 Taxon sampling: We collected 18 black salamanders from 9 localities in inland regions of

143 southeastern Humboldt County at the contact zone between A. flavipunctatus and $A$.

144 klamathensis sp. nov. in order to pinpoint the boundary between these species (Table 1). The

145 sampling transect follows Alderpoint Road between the Eel River at Alderpoint north through

146 Bridgeville and into the Van Duzen drainage. All samples are deposited at the Museum of

147 Vertebrate Zoology, UC Berkeley.

148 Animal use was approved by the University of California, Berkeley, IACUC protocol

149 \#R093-0205 issued to DBW. Collection of live salamanders in the field was authorized by the

150 California Natural Resources Agency, Department of Fish and Wildlife (approval\# SC-2860

151 issued to DBW).

152

153 Genetic analysis: We sequenced a portion of the mitochondrial ND4 gene from the salamanders

154 collected in SE Humboldt County following methods described in Reilly \& Wake (2015). These

155 sequences were combined using GENEIOUS (Kearse et al., 2012) and aligned to existing

156 mitochondrial sequences (ND4, 12S, and cytb) for Aneides flavipunctatus used in previous

157 studies (Rissler \& Apodaca, 2007; Reilly et al., 2012; Reilly et al., 2013; Reilly \& Wake, 2015)

158 using MUSCLE (Edgar, 2004).

159 Phylogenetic analysis was performed using RAxML (Stamatakis, 2014) in order to place

160 new samples into known mtDNA clades described in Reilly \& Wake (2015). The best fit model

161 of sequence evolution $(\mathrm{GTR}+\mathrm{I}+\mathrm{G})$ was determined using jModelTest (Posada, 2008), and 1000

162 bootstrap replicates were performed to evaluate nodal support. The tree was rooted with Aneides

163 lugubris, A. vagrans, A. ferreus, and A. hardii sequences used in Reilly and Wake (2015).

164

165 Morphological analyses: We measured morphological characters to the nearest $0.1 \mathrm{~mm}$ from

166 adult Aneides flavipunctatus specimens representing the species described in this paper. We

167 used the Northern "Central Core" clade from Reilly \& Wake (2015) to represent $A$.

168 flavipunctatus because we are most interested in the change in morphology close to the southern

169 Humboldt contact zone. Males and females were analyzed separately with measurements from

170 10-11 adults per population for A. niger, A. iecanus, A. klamathensis, and North Central Core $A$.

171 flavipunctatus. Measurements taken include snout to the posterior margin of the vent (SVL),

172 axilla to groin (AG), head width (HW), forelimb length (FLL), hind limb length (HLL), right

Peer] reviewing PDF | (2019:04:36410:1:1:NEW 22 Jun 2019) 
173 hand (RH), right foot (RF), longest toe (LT), distance between eyes (DBE), internarial distance 174 (ID), and snout to gular fold (SG) (see Bingham et al. 2018). Morphological analyses were

175 calculated using the MASS package (Venables \& Ripley, 2002) implemented in R (R Core Team

176 2018) to differentiate the four species. All measurements were log transformed before

177 conducting a linear discriminant function analysis (DFA) followed by a classification matrix,

178 obtained from the DFA, to calculate classification probabilities of the four species.

179 Osteological descriptions of each species are presented based on the examination of 180 cleared and stained specimens housed at the Museum of Vertebrate Zoology. The number of 181 specimens, their sex, age class, and museum numbers are presented in the osteological 182 descriptions for each species.

183

184 Nomenclatural acts: The electronic version of this article in Portable Document Format (PDF)

185 will represent a published work according to the International Commission on Zoological

186 Nomenclature (ICZN), and hence the new names contained in the electronic version are

187 effectively published under that Code from the electronic edition alone. This published work

188 and the nomenclatural acts it contains have been registered in ZooBank, the online registration

189 system for the ICZN. The ZooBank LSIDs (Life Science Identifiers) can be resolved and the

190 associated information viewed through any standard web browser by appending the LSID to the 191 prefix http://zoobank.org/. The LSID for this publication is:

192 urn:lsid:zoobank.org:pub:D11721DC-3000-4EA6-BC51-87D47D3277CB. The online version

193 of this work is archived and available from the following digital repositories: PeerJ, PubMed

194 Central and CLOCKSS.

195

196

\section{Results}

197

198 Contact zone sampling and genetic analysis: Sample localities and their associated species assignment can be viewed in Figure 2 with numbers alongside relevant localities. Mitochondrial $N D 4$ haplotypes for six of the newly sequenced salamanders from the three southern-most localities belonged to A. flavipunctatus, while haplotypes for 12 salamanders from the six more northern localities belonged to A. klamathensis (Fig. 2). These haplotypes were grouped within these clades with high bootstrap support (Fig. 3). The two haplotype groups are approximately 
$2045.4 \%$ divergent (Reilly \& Wake, 2015). Locality numbers of samples within the tree are noted

205 by the bold number after the museum number. This narrows the contact zone in eastern

206 Humboldt County between A. flavipunctatus and A. klamathensis to a $\sim 3 \mathrm{~km}$ region between

207 Dobbyn Creek and the town of Blocksburg.

208

209 Morphological analyses: Measurements can be found in Table S1. For the male-specific LDA

210 analysis 0.686 of the variation was captured in the first linear discriminant, 0.192 in the second,

211 and 0.122 in the third. In the female-specific analysis 0.504 of the variation was captured in the

212 first linear discriminant, 0.356 in the second, and 0.140 in the third. Plotting of linear

213 discriminant 1 vs 2 for both males and females can be found in Figure 4. Attempts at using the

214 DFA to classify adult salamanders from the southern Humboldt contact zone were relatively

215 unsuccessful, suggesting a lack of morphological distinctiveness between A. flavipunctatus and

216 A. klamathensis along the Alderpoint Road contact zone.

217

218 Geographic range estimation: The geographical ranges of the four species have been estimated

219 based on previous genetic studies as well as our judgement and experience in the field. All

220 museum localities have been downloaded from VertNet (vertnet.org) and plotted according to

221 species designations (Fig. 5). In some cases, such as the records from western Tehama and

222 western Glenn Counties, even examination of specimens and collector field notes were not

223 sufficient to assign them to a species at this time.

224

225 Systematics

226

227

228

229

230

Aneides klamathensis, new species

Aneides flavipunctatus (part) - Stebbins, 1951

Aneides sequoiensis (part; nomen nudum) - Dubois and Raffaëlli, 2009

231

232 Figures $6-7$

233

Peer] reviewing PDF | (2019:04:36410:1:1:NEW 22 Jun 2019) 
234 Holotype: MVZ 291759 (Museum of Vertebrate Zoology, University of California, Berkeley, 235 California, USA) (Field number: SBR 265), an adult male from $\sim 1 \mathrm{~km}$ east of Klamath, Del 236 Norte County, California (coordinates $41.52213 \mathrm{~N},-123.99712 \mathrm{~W}$; error $\pm 9 \mathrm{~m}$; elevation $20 \mathrm{~m}$ ), 237 collected by S. B. Reilly and D. B. Wake on 10 November 2013.

238

239

240

241

242

243

244

245

246

247

248

249

250

251

252

253

254

255

256

257

258

259

260

261

262

263

264

Paratypes: MVZ 217468 (Female, F), 217469 (Male, M), East Fork Rd, 1 mi (1.6 km) N Hwy 299 at Helena, Trinity Co, CA (40.7825366 N, -123.1283051 W); MVZ 124234 (M), 124236 (F), 124237 (F), Big Slide Campground, $7.2 \mathrm{mi}$ (11.6 km) N (rd) Hyampom, Trinity Co, CA (40.6792098 N, - $123.5086485 \mathrm{~W})$; MVZ 184687 (F, cleared and stained), $12.6 \mathrm{mi}(20.3 \mathrm{~km}) \mathrm{N}$ Hyampom, Humboldt Co, CA (40.7217669 N, -123.5516924 W); (MVZ 124229 (M), 124230 (F), Hwy 36, $0.3 \mathrm{mi}(0.48 \mathrm{~km})$ W Mad River (town), Trinity Co, CA (40.4545945 N, 125.5103053 W); MVZ 196362 (M), 10.2 mi (16.4 km) E Big Bar, Trinity Co, CA (40.7622585 N, -123.0983789 W); MVZ 124223 (F), 2.8 mi (4.5 km) E (rd) Hawkins Bar, along state hwy 299, Trinity Co., CA (40.8497268 N, -123.4848539 W); MVZ 124220 (F), 124221 (F), MVZ 124222 (M), $0.5 \mathrm{mi}(0.8 \mathrm{~km})$ E Junction City on hwy 299, Trinity Co, CA (40.7278373 N, 123.0400778 W); MVZ 124225 (F), Little Bidden Creek, $1.4 \mathrm{mi}(2.25 \mathrm{~km}) \mathrm{S}$ and $1.3 \mathrm{mi}(2.1 \mathrm{~km})$ E Burnt Ranch, Trinity Co, CA (40.783976 N, -123.458849 W); MVZ 124238 (M), state hwy 2993.5 mi E (rd) Salyer, Trinity Co, CA (40.8739495 N, -123.5337218 W); MVZ 184682 (M, cleared and stained), state hwy $2992 \mathrm{mi}(3.2 \mathrm{~km})$ E Salyer, Trinity Co, CA (40.8832655 N, 123.5545419 E); MVZ 217462 (F), rest area $2.5 \mathrm{mi}$ (4 km) SE Salyer, Trinity Co, CA (40.8832291 N, -123.5469397 W); MVZ 217471 (F), 12.2 mi (19.6 km) SE Salyer, Trinity Co, CA (40.76509 N, -123.42883 W); MVZ 196349 (M), hwy 96, 5.5 mi (8.9 km) S (rd) Weitchpec, Humboldt Co, CA (41.1252012 N, -123.6837375 W); MVZ 124006 (M), $1 \mathrm{mi}(1.6 \mathrm{~km}) \mathrm{N}$ Weitchpec, Humboldt Co, CA (41.18762 N, -123.72346 W); MVZ 199753 (F, cleared and stained), $4.7 \mathrm{mi}(5.6 \mathrm{~km}) \mathrm{S}$ Weitchpec, Humboldt Co, CA (41.1346733 N, -123.6838263 W); MVZ 124011 (M), $4.9 \mathrm{mi}(7.9 \mathrm{~km}) \mathrm{S}$ Weitchpec on hwy 96, Humboldt Co, CA (41.1326067 N, 123.6863681 W), MVZ $221018(\mathrm{M})$, ca $0.3 \mathrm{mi}(0.5 \mathrm{~km}) \mathrm{NW}$ junction of unnamed rd and Maple Creek Rd, $6.5 \mathrm{mi}(10.5 \mathrm{~km})$ SE Korbel, Humboldt So, CA (40.8360231 N, -123.8907322 W).

Diagnosis: A large (males to more than $80 \mathrm{~mm} \mathrm{SL}$; females to more than $85 \mathrm{~mm} \mathrm{SL}$ ) member of the Aneides flavipunctatus complex, subgenus Aneides (two subgenera in the genus, proposed by 
265 Dubois and Raffaëlli, 2012, and discussed by Wake, 2016), distinguished from members of the 266 subgenus Castaneides by larger size (A. aeneus less than $70 \mathrm{SL}$ ) and more robust body and tail, 267 with relatively much shorter limbs and digits and blackish rather than greenish coloration.

268 Distinguished from other members of subgenus Aneides as follows: from A. hardii by its much 269 larger size ( $A$. hardii less than $60 \mathrm{SL}$ ), more robust head, body and tail, and subdued sexual 270 dimorphism; from the somewhat larger A. lugubris (some individuals exceed $100 \mathrm{~mm} \mathrm{SL}$ ) by 271 darker ground coloration, more robust and less prehensile and tapered tail, and much shorter 272 limbs and digits; from A. ferreus and A. vagrans by larger size (these species rarely exceed 75 $273 \mathrm{~mm} \mathrm{SL}$ ), more robust and less prehensile and tapered tail, and much shorter limbs and digits.

274 The new species is distinguished from other members of the Aneides flavipunctatus complex as 275 follows: from A. flavipunctatus by geographic range and DNA sequences, from A. iecanus by 276 having only relatively few small dorsal iridophores and in averaging 17 rather than 16 trunk 277 vertebrae, from A. niger by coloration (A. niger is typically solid black with no whitish or gray 278 markings).

279

280

281

Description: Aneides klamathensis is a large, robust plethodontid salamander that resembles

282 other members of the Aneides flavipunctatus complex in its morphology. Standard length in the type series is $68.2-80.6$, mean $74.5+/-3.4$, for 11 adult males; $65.4-84.8$, mean $71.7+/-5.3$, for 10 adult females. Heads are very large and the jaw muscles of adults of both sexes, but especially large males, are greatly expanded and bulge from the general outlines of the head. Head width of 11 males is $10.5-13.9$, mean $12.5+/-0.92(0.15-0.19$, mean $0.17+/-0.01$ times $\mathrm{SL}) ; 10$ females $9.5-11.7$, mean $10.5+/-0.65(0.13-0.16$, mean $0.15+/-0.01$ times SL). The jaws are especially strong and bear a few large maxillary ( $1-7$ each side) and mandibular (4-7 each side) teeth. Limbs are of modest length but relatively robust. Combined limb length (CLL) is $0.45-0.49$, mean $0.47+/-0.02 \mathrm{SL}$ in 11 males; CLL/SL $0.42-0.48$, mean $0.46+/-0.02$ in 10 females. Limb interval is $0.5-3$, mean $1.9+/-0.84$ in 11 males; $2-4$, mean $2.1+/-0.24$ in 10 females. Tails generally are robust but nearly all of them show signs of some regeneration, especially near the tip. Tails never are more than $0.82 \mathrm{SL}$. Digits, while long and slender, are

293 less-so than those of other Aneides in California. Digits are modestly expanded terminally; the 294 longest digits (\#3) on the pes do not exceed 4.3. 
296 Description of the Holotype: The holotype is a large (76.7 SL) male that in preservative is 297 generally very dark black over all its dorsal surfaces in preservation. There are scattered small

298 whitish spots on the neck and sparsely along the lateral margins of the dorsum, with some

299 scattered on the tail and its lateral surfaces. Whitish spots and blotches are prominent along the

300 flanks of the trunk. Small but prominent whitish spots are present on both proximal and distal

301 portions of the limbs and the dorsal surfaces of the hands and feet, although the fingers and toes

302 are nearly unpigmented and appear gray in preservation. The tail is robust proximally but then

303 sharpens to a point; the last $15 \%$ of the dorsal surface of the tail is unpigmented and appears

304 gray. The tail is relatively short and is at least partially regenerated near the tip. The snout is

305 broad and relatively flat, and it is broadly rounded at its tip. Nasolabial protuberances are

306 modest in development and are unpigmented along the nasolabial groove. The eyes are

307 moderately large and prominent but not very protruded from the rest of the head. The enlarged

308 jaw muscles bulge outward well beyond the eyes. Integumentary grooves of the head are

309 relatively prominent, and they tend to lose pigment in their deepest extents. The neck region is

310 well defined. The limbs are relatively short, as are the digits. The first digits of both manus and

311 pes are small and not prominent. The fourth digit of the manus and fifth of the pes are much

312 shorter than the preceding digit and they are about the same length, or slightly shorter, than the

313 second digit. Even the longest digits are only modestly expanded distally, with well developed

314 subterminal pads. Ventral surfaces are generally dark black. However, there is a large and

315 prominent ovoid mental gland that is lightly pigmented to unpigmented, and the pale area

316 occupies about $40 \%$ of the gular region. The gular fold is unpigmented, as are the palms of the

317 manus and pes. There is a general loss of pigment on the undersides of the limbs, giving them a

318 generally gray appearance. The last $20 \%$ of the tail is unpigmented.

319

320 Measurements (in mm), limb interval and tooth counts of the holotype: SL 78.7, Tail

321 (regenerated) 50.7, Ax-Gr 42.8, S-G 15.7, HW 12.0, FLL 15.9, HLL 18.5, RH 6.3, RF 8.2,

322 Minimal distance between eyes 5.5, Internarial distance 3.0, Horizontal eye diameter 3.4,

323 Shoulder width 9.6, Length $3^{\text {rd }}$ toe 3.7, Length $5^{\text {th }}$ toe 2.4, Eye to nostril 3.4, Eye to snout 4.8,

324 Width of mental gland 4.2, Length of mental gland 4.0, Head depth 6.1, Eyelid width 2.3, Eyelid

325 length 3.6, Snout to forelimb 22.4, Diameter of external naris 0.4, Distance snout extends beyond

326 mandible 1.2, Snout to anterior margin of vent 69.6, Tail width 5.6, Tail depth 5.5, Maximal 
327 width of broadest toe 0.8 , Limb interval 2.5, Number of costal grooves 15, Premaxillary teeth 11,

328 Maxillary teeth 3-2 small anterior and 2.-2 enlarged posterior, Vomerine teeth not countable.

329

330 Coloration: Paedomorphic coloration in the sense of Larson (1980) and Lynch (1981),

331 consisting of heavy frosting of greenish gray pigment overlying black ground color on the dorsal

332 surfaces and especially on the flanks of the trunk, where there is a sharp boundary with the

333 generally black ventral coloration. Whitish to cream-colored or faint yellow spots of small to

334 moderate size are evident on the dorsal surfaces of the limbs but are widely scattered and few in

335 number on other dorsal surfaces (Fig. 6, 7).

336

337 Coloration of the Holotype in life (from field notes of S. B. Reilly): Intense whitish

338 spotting/frosting on lateral sides and arms (Fig. 6a), light speckling on belly, and gold/gray

339 frosting on back (Fig. 6b-c, 7).

340

341 Osteology: Information was derived from 7 adult males and 6 adult females, cleared and singly

342 stained many years ago and only useful for some details. The largest individual is an $88.5 \mathrm{SL}$

343 female from Hyampom, Trinity Co.; the smallest individual is $67.3 \mathrm{SL}$ from Weitchpec,

344 Humboldt County. One female has 18 trunk vertebrae and a female and a male have 16; all

345 others have 17 trunk vertebrae. Vomerine teeth, not countable in the strongly jawed preserved

346 specimens, are small and few in number. The smallest individual has no vomerine teeth. In

347 other specimens, numbers range from 2-2 (the largest individual) to 5-5 (a 71.5 SL female).

348 Premaxillary teeth vary from 4-8 in males and 3-7 in females. Large maxillary teeth range from

$3492-4$ per bone in both sexes; small maxillary teeth range from 0 to 3 per bone in males and from

3501 to 3 in females. Large mandibular teeth range from 2-4 in males and 1-4 in females.

351 The osteology of Aneides flavipunctatus was described in detail by Wake (1963) based

352 on 13 singly cleared and stained and two skeletonized specimens. This was a sample of mixed

353 origin, in part Aneides flavipunctatus (Mendocino Co.) and in part Aneides niger (Santa Cruz

354 Co.). We studied the osteology of three individuals of Aneides klamathensis in detail and

355 compared them to the descriptions in Wake (1963). Two large female (MVZ 18468 - 88.5 SL,

356 MVZ 199753 - 85.0 SL) and a large male (MVZ 184682 - 79.7 SL) were available as cleared

357 and stained specimens in the MVZ collection. We compared them with the geographically most 
358 proximal member of A. flavipunctatus, a large male (MVZ 124079 - 80.1 SL) from Alderpoint, 359 Humboldt Co, CA $\left(40.1767267^{\circ} \mathrm{N},-123.6102663^{\circ} \mathrm{W}\right)$, within two or three km of the nearest $A$.

360 klamathensis. All specimens have 17 trunk vertebrae. MVZ 199735 and 124079 are especially

361

362

363

364

365

366

367

368

369

370

371

372

373

374

375

376

377

378

379

380

381

382

383

384

385

386

387

388

well prepared individuals doubly stained for bone and cartilage; these were used for making detailed comparisons with the descriptions of Wake (1963). We found no differences between the two species compared, nor with the published descriptions.

The skulls are very solid and well articulated and closely resemble the descriptions and figures (especially Fig. 3 C \& D) in Wake (1963). Notable features are the tight articulation of the frontals and parietals on the skull roof, the well articulated facial region of the skull, and the prominent, high crests on the oticoccipitals. These crests extend far posterior and the most caudal portion of the skull. There is no indication of any coossification of the skin of the snout and the underlying bones (as is prominent in A. lugubris, Wake, 1963)

The premaxillary and maxillaries are especially stout bones. The posterior part of each maxillary lacks teeth and is shaped like a cleaver, extending ventrally to the level of the tips of the enlarged maxillary teeth. The edentulous portion occupies more than half the length of the entire bone. Each maxillary has an interlocking articulation with the adjoining prefrontal. The ascending processes of the premaxillary envelop the internasal fontanelle, but while they approach each other behind the fontanelle, they do not articulate. The mandible is a large, robust bone and the jaw suspension, especially the quadrate and squamosal, are robust bones that have strengthening struts aligned more or less vertically. The bodies of the vomers are large and well articulated with each other along the midline. However, the posterior parts of the bones are reduced in size. Preorbital processes are absent and the teeth are relatively very small and few in number. Posterior vomerine patches of teeth approach each other at the midline but they are not in contact.

The jaw dentition is remarkably large and strong, but the teeth are not numerous. While the maxillary may bear as many as six teeth (a female), typically only two or three are both enlarged and ankylosed. Teeth are replaced from anterior to posterior along the jaw, with alternate positional replacement. Thus, two or even three rows of teeth are present and while only at most three are ankylosed at any one time, the larger replacement teeth protrude from the skin and have some degree of function. The same pattern is found on the dentary, but the ankylosed teeth are fewer in number and are even longer and stronger than those on the

Peer) reviewing PDF | (2019:04:36410:1:1:NEW 22 Jun 2019) 
389

390

391

392

393

394

395

396

397

398

399

400

401

402

403

404

405

406

407

408

409

410

411

412 Geographic Distribution: This is the northernmost member of the A. flavipunctatus complex. It

413 ranges southward from the upper reaches of the Applegate river drainage in Jackson Co.,

414 extreme southern Oregon and the southern bank of the Smith River in Del Norte Co., CA, south

415 through Del Norte and Humboldt counties to the Van Duzen River and its tributaries, and east

416 along the Klamath and Trinity rivers into Trinity and western Siskiyou counties, CA (Fig. 5).

417 The species is distributed mainly at elevations below $500 \mathrm{~m}$ elevation but is known to occur as

418 high as about $1000 \mathrm{~m}$ near Hilt, Siskiyou Co., CA, at the extreme northeastern extent of it range. 
419 For more details on the contact zone between A. klamathensis and A. flavipunctatus in inland

420 Humboldt County see discussion below.

421

422 Etymology: The Klamath Mountains, for which this species is named, is one of eleven

423 geomorphic provinces in California. These mountains are a rare east to west oriented range in 424 northwestern California and southwestern Oregon, with an elevation extending above $2750 \mathrm{~m}$.

425 The Klamath River flows through the length of the range, and other important rivers include the 426 Trinity and branches of the Rogue (especially Applegate and Illinois). The range harbors rich 427 biodiversity and endemism and is home to the largest number of conifers on Earth (about thirty 428 species including eighteen in a single square mile $\left[2.6 \mathrm{~km}^{2}\right]$ ).

429

430 Remarks: The first suggestion that Aneides flavipunctatus was a multispecies complex was 431 presented in the unpublished doctoral dissertation of Lowe (1950). Populations from the north 432 coastal portion of the range of the complex south to the Longvale region of Mendocino County, 433 CA, were recognized as a distinct subspecies and assigned a manuscript name. This distinction 434 was based on the apparent preference for rock talus microhabitats, as well as the gray or greenish 435 frosted coloration, which Lowe hypothesized was adapted for crypsis. This form was thought to 436 range "in the outer Coast Ranges of northern California from the Klamath River of northern 437 Humboldt County southward into Mendocino County in the Laytonville-Longvale area, and 438 westward to the coastline" (Lowe. 1950 p. 3). The southern part of this range extends far to the 439 south of the range of $A$. klamathensis, and the proposed type locality ("Squaw Creek, 1.3 miles north of Cummings, Mendocino County, California”, Lowe, 1950 p. 56; approximately $39.831582^{\circ} \mathrm{N},-123.650227^{\circ} \mathrm{W}$ ) is from what is now recognized as the northern segment

442 (Central Core Clade 1, mitochondrial clade CM; Reilly and Wake, 2015, Fig. 3A) of the 443 relatively wide-ranging $A$. flavipunctatus (sensu stricto), based on our current analysis.

The first functional explanation for the frosted coloration of the northwestern populations was paedomorphosis; proportions and coloration typical of juveniles are retained into adulthood

446 (Larson, 1980). Larson postulated that many of the shape and proportional differences of $A$.

447 klamathensis may not be adaptive, but rather a byproduct of selection for cryptic coloration and 448 associated juvenile proportions. Lynch (1981) conducted a detailed color analysis and also 449 concluded that these populations maintained the typical juvenile brassy pigmentation into 
450 adulthood. He noted that adults differed from juveniles in having more deeply embedded 451 iridophores, which gave them a darker copper-toned color rather than the yellowish green 452 coloration of juveniles. Based on this retention of juvenile coloration and external proportions, 453 Lynch (1981) found that what is now considered A. klamathensis had the highest 454 "paedomorphism index" level of all populations of the flavipunctatus complex.

455 Larson included two populations of A. klamathensis in his allozymic study, his populations

4567 and 8. They were not especially distinctive in any way, but they were relatively most 457 differentiated with respect to A. iecanus (Nei D 0.099 - 0.149) and especially A. niger (Nei D $4580.170-0.215)$. The range of values of Nei D with respect to A. flavipunctatus was $0.040-$ 459 0.117. The only fixed difference (for the allozyme Got-1) was in comparison to A. iecanus. Population genetic analysis of samples from the region found that the Klamath watershed may have acted as a Pleistocene refugium, and that the Smith and Rogue River watersheds have been recently colonized from Klamath River populations (Reilly et al., 2013). While $A$. klamathensis has not been found in sympatry or close parapatry with A. iecanus, it is parapatric with A. flavipunctatus in southern Humboldt County south of the Van Duzen River (Reilly \& Wake, 2015). By studying variation in an mtDNA gene (ND4) along a north-south transect in southeastern Humboldt County, we narrowed this zone of contact to $\sim 3 \mathrm{~km}$, between Dobbyn Creek and the town of Blocksburg (Figs. 2 and 5). Coalescent analysis of 13 nuclear loci estimated that gene flow from A. klamathensis sp. nov. into A. flavipunctatus is $2 \mathrm{Nm}=0.25$, with $2 \mathrm{Nm}=0.53$ in the opposite direction (Reilly \& Wake, 2015). This suggests that infrequent migration and hybridization occurs between these lineages. Both the mtDNA phylogeny and nDNA population clustering analyses find a narrow, unambiguous zone of contact (Reilly \& Wake, 2015). The mtDNA+nDNA and nDNA coalescent species tree analyses find that $A$. klamathensis sp. nov. is sister to A. flavipunctatus, a finding that is in disagreement with the mtDNA-only phylogeny (which places A. klamathensis as sister to A. iecanus, Fig. 8). "1950". This is a manuscript name from the unpublished portion of the doctoral thesis of Lowe (1950) and hence is unavailable (a nomen nudum). Furthermore, while it was intended to refer to the taxon we have named Aneides klamathensis, the type locality used by Lowe is within the 479 geographic range of Aneides flavipunctatus, in the sense of the use of that taxon in this work. 
481

482

483

484

485

486

487

488

489

490

491

492

493

494

495

496

497

498

499

500

501

502

503

504

505

506

507

508

509

510

511

\section{Aneides niger Myers and Maslin 1948}

Autodax iëcanus (part) - Van Denburgh, 1896

Aneides flavipunctatus (part) - Storer, 1925

Aneides flavipunctatus niger - Myers \& Maslin, 1948

Santa Cruz Black Salamander

Figure 9

Holotype: Originally Stanford Natural History Museum (SNHM) \#2938, currently CAS SUA 2918.

Type Locality: "near the forks of Waddell Creek, Santa Cruz County" (approximately $37.133876^{\circ} \mathrm{N},-122.267535^{\circ} \mathrm{W}, 26$ m elevation), CA; collected by G. S. Myers and M. W. Brown.

Diagnosis: A large (males and females exceed $80 \mathrm{~mm} \mathrm{SL}$ ) member of the Aneides flavipunctatus complex, subgenus Aneides, distinguished from members of the subgenus Castaneides by larger size (A. aeneus less than $70 \mathrm{SL}$ ), rounded rather than flattened head and body, and more robust body and tail, with relative much shorter limbs and digits and blackish rather than greenish coloration. Distinguished from other members of subgenus Aneides as follows: from $A$. hardii by its much larger size ( $A$. hardii less than $60 \mathrm{SL}$ ), more robust head, body and tail, and subdued sexual dimorphism; from the somewhat larger A. lugubris (some individuals exceed $100 \mathrm{~mm} \mathrm{SL}$ ) by darker ground coloration, more robust and less prehensile and tapered tail, and much shorter limbs and digits; from $A$. ferreus and $A$. vagrans by larger size (these species rarely exceed $75 \mathrm{~mm} \mathrm{SL}$ ), more robust and less prehensile and tapered tail, and much shorter limbs and digits. This species is distinguished from other members of the Aneides flavipunctatus complex by its nearly uniform black coloration in adults; juveniles have numerous tiny white dorsal spots that are lost progressively at larger sizes (Lynch, 1981) (Fig. 9); it is further distinguished from $A$. iecanus by having an average number of trunk vertebrae of 17 rather than 16. 
512 Description: Aneides niger, like other members of the Aneides flavipunctatus complex, is a

513 large, robust salamander. Lynch (1981) reported SL for combined population samples from

514 Santa Clara (13 males, mean SL 69.2; 16 females, mean SL 68.6) and Santa Cruz counties (15

515 males, mean SL 65.7; 17 females, mean SL 60.8). We measured samples of large adults from

516 across the range and obtained values of SL of $68.8-85.7$, mean $75.9+/-6.0$ for 10 males; $58.3-$

51773.7 , mean $67.7+/-5.2$ for 10 females. As in other members of this complex, heads are large

518 and laterally expanded behind the eyes in both sexes but especially so in large males. Head

519 width of 10 males is $10.5-16.3$, mean $12.9+/-1.8(0.15-0.19$, mean $0.17+/-0.01$ times SL);

52010 females $8.9-10.9$, mean $10.2+/-1.8(0.14-0.17$, mean $0.15+/-0.01$ times SL). The strong

521 jaws bear few maxillary and mandibular teeth, but the longest one to three teeth are very large.

522 Limbs are moderately long and robust. Combined limb length (CLL)/SL) is $0.41-0.46$, mean

$5230.43+/-0.02$ in males; $0.42-0.49$, mean $0.43+/-0.03$ in females. Limb interval is $2.5-4$, mean

$5243.2+/-0.54$ in males; 2 - 3.5, mean 3.0+/- 0.47 in females. Tails are robust and moderately

525 long, but all show signs of regeneration. Only three of twenty individuals have tails that are 0.8

526 times SL or longer (the longest is $0.87 \mathrm{SL}$ in the largest male). Digits are long and slender and

527 are terminally expanded. The longest digit on the pes is 3.9.

528

529 Geographic Distribution: Aneides niger occurs only in the Santa Cruz Mountains on the lower

530 San Francisco Peninsula in Santa Cruz, southwestern Santa Clara, and extreme southern and

531 eastern San Mateo counties, California (Fig. 5). The southernmost locality is at approximately

$53237^{\circ} \mathrm{N}$. The species occurs from near sea level to elevations of approximately $800 \mathrm{~m}$. This is the

533 most semiaquatic member of the complex and individuals are commonly encountered in the

534 margins of rapidly flowing streams and in wet, rocky seeps. Individuals are rarely encountered

535 far from water.

536

537 Etymology: The name refers to the solid black coloration of adults of this species.

538

539 Remarks: Myers and Maslin (1948) based their description of A. f. niger on the absence of spots

540 (a similar coloration is found in coastal Sonoma and Mendocino Counties) and the disjunct

541 distribution. Lowe (1950) concurred with this subspecific designation and added ecological

542 evidence, specifically the semiaquatic microhabitat preference (Myers and Maslin had earlier 
543 noted its "hydrophilous" nature and compared its habitat to that of Desmognathus fuscus).

544 However, Lynch (1974) suggested that the coloration and distribution criteria used by Myers and

545 Maslin were largely invalid because they had not obtained sufficient specimens from localities

546 throughout the range of the complex to be able to conduct appropriate comparisons. Later,

547 Lynch (1981) concluded that Myers and Maslin's claim that A. f. niger had relatively shorter

548 limbs was driven by a smaller mean SVL of $A$. f. niger specimens $(65 \mathrm{~mm})$ examined compared

549 to specimens examined from the main range $(75 \mathrm{~mm})$, and that this difference was ontogenetic in 550 nature.

551 Lynch (1981) meticulously documented coloration characters from throughout the range

552 and found that iridophore size in A. f. niger did not increase with body size, as in populations

553 from the main part of the geographic range of the complex. Furthermore, A. f. niger showed the

554 most dramatic reduction of dorsal iridophores and a denser melanophore network on the chin of

555 any population. His morphological analysis revealed that $A$. f. niger has slightly shorter tails

556 relative to body length than main range populations, and that $95 \%$ of $A$. f. niger samples

557 examined contained 17 trunk vertebrae while the nearest populations in Sonoma and Napa

558 Counties had a modal count of 16 trunk vertebrae. Lynch created a paedomorphism index to

559 quantify the degree to which each population of A. flavipunctatus retained juvenile

560 characteristics. He found that A.f. niger contained the lowest paedomorphism index score of any

561 A. flavipunctatus populations, suggesting that they retain fewer juvenile characteristics than any

562 other population.

563 Both Lowe and Lynch noticed that A. f. niger was active at the surface by day in

564 atmospheric conditions of nearly $100 \%$ humidity in the wet, heavily shaded streamside habitat

565 they frequent. Individuals often are found in contact with, or submerged in, standing water. The

566 only other population with a similar microhabitat preference is the Shasta County population $(A$.

567 iecanus), which may explain the phenetic similarity of A. niger to A. iecanus calculated by

568 Lynch, possibly a manifestation of convergent evolutionary adaptations of these two species to a

569 semi-aquatic way of life. However, a PCA of environmental space revealed that $A$. f. niger

570 occupies a distinct environmental space when compared to the rest of the range (Rissler \&

571 Apodaca 2007).

572 Highton (2000) reanalyzed a large number of allozymic studies of salamanders and

573 offered alternative interpretations of their taxonomic significance. One of these was the Aneides 
574 study of Larson (1980), to which he devoted a short paragraph. Highton advocates a level of

575 allozymic genetic distance of about 0.15 as approximating the level appropriate for species

576 recognition. He found three such groups in Larson's Aneides flavipunctatus data and concluded

577 "the taxonomic hypothesis that these groups are three different species is more strongly

578 supported by the available evidence than the hypothesis that they represent a single species".

579 The allozymic study of Larson (1980) obtained estimates of Nei genetic distance from A. niger

580 as follows: A. klamathensis $0.170-0.215$, A. iecanus 0.222 , A. flavipunctatus $0.130-0.182$.

581 Additionally, Larson estimated that $A$. f. niger had first diverged from A. iecanus nearly 3 million

582 years ago and had subsequently diverged from the main range approximately 2.4 million years 583 ago.

584 Evidence has only grown stronger in the intervening decades, including data from mtDNA 585 and nuclear gene sequences (reviewed by Reilly and Wake, 2015) and the new morphometrical 586 analysis presented herein. While Rissler and Apodaca (2007) suggested that A.f. niger

587 represented a distinct species they did not formally recognize it as such. Nevertheless, the on-

588 line database Amphibian Species of the World 6.0, an Online Reference

589 (http://research.amnh.org/vz/herpetology/amphibia/Amphibia/Caudata/Plethodontidae/Plethodon

590 tinae/Aneides/Aneides-niger) recognized the taxon as a full species, citing Rissler and Apodaca

591 "by implication" (also citing, Collins \& Taggart, 2009, and Dubois and Raffaelli, 2012, although

592 both are simply lists).

593

594 Redescription of Aneides iecanus (Cope 1883)

$595 \quad$ Plethodon iëcanus - Cope, 1883

596 Anaides iëcanus - Cope, 1886

597 Autodax iëcanus - Cope, 1889

598 Aneides iecanus - Grinnell \& Camp, 1917

599 Aneides flavipunctatus (part) - Storer, 1925

600 Shasta Black Salamander

601

602 Figures $10-11$

603

604 Holotype: ANSP 14061 (Fowler \& Dunn, 1917) 
606 Type Locality: “- near the United States fish-hatching establishment on the McCloud River, in 607 Shiasta (sic) County". Collected by E. D. Cope.

608

609 Diagnosis: A large (some individuals exceed $80 \mathrm{~mm} \mathrm{SL}$ ) member of the Aneides flavipunctatus 610 complex, subgenus Aneides, distinguished from members of the subgenus Castaneides by larger 611 size (A. aeneus less than $70 \mathrm{SL}$ ), rounded rather than flattened head and body, more robust body 612 and tail, with relative much shorter limbs and digits and blackish rather than greenish coloration. 613 Distinguished from other members of subgenus Aneides as follows: from $A$. hardii by its much

614 larger size (A. hardii less than $60 \mathrm{SL}$ ), more robust head, body and tail, and subdued sexual 615 dimorphism; from the somewhat larger A. lugubris (some individuals exceed $100 \mathrm{~mm} \mathrm{SL}$ ) by 616 darker ground coloration, more robust and less prehensile and tapered tail, and much shorter 617 limbs and digits; from $A$. ferreus and A. vagrans by larger size (these species rarely exceed 75 $618 \mathrm{~mm} \mathrm{SL}$ ), more robust and less prehensile and tapered tail, and much shorter limbs and digits. 619 This species is distinguished from other members of the Aneides flavipunctatus complex by its 620 heavily speckled head, body and tail (Lynch, 1981) (Fig. 10, 11); it is further distinguished from 621 both A. klamathensis and A. niger by having an average of 16 rather than 17 trunk vertebrae.

622

623 Description: Aneides iecanus, like other members of the Aneides flavipunctatus complex, is a 624 large, robust salamander. We measured samples of large adults from across the range and 625 obtained values of SL of 69.9 - 81.6, mean 75.8 +/- 3.9 for 10 males; 60.9 - 78.7, mean 70.1 +/6265.5 for 10 females. As in other members of this complex, heads are large and laterally expanded 627 behind the eyes in both sexes but especially so in large males. Head width of 10 males is $11.0-$ 628 13.3, mean 12.5 +/- 0.65 (mean 0.16 +/- 0.01 times SL); 10 females 8.9 - 10.8, mean 10.0 +/6290.64 (mean 0.14 +/- 0.01 times SL). The strong jaws bear few maxillary and mandibular teeth, 630 but the longest one to three teeth are very large. The large teeth are cylindrical rather than 631 flattened. Limbs are moderately long and robust. Combined limb length (CLL) is 26.5 - 35.9, 632 mean 30.0+/- 3.4 in males (CLL/SL 0.43 - 0.50, mean 0.41 +/- 0.13; CLL 27.0 - 33.0, mean $63330.6+/-1.7$ in females (CLL/SL $0.41-0.47$, mean $0.44+/-0.02$ ). Limb interval is 2 - 3, mean $6342.2+/-0.35$ in males; $2.5-4$, mean $3.4+/-0.52$ in females. Tails are robust and moderately 635 long but most show signs of regeneration. The longest tails reach $0.85 \mathrm{SL}$ in males and $0.78 \mathrm{SL}$ 
636 in females. Digits are long and slender, and are terminally expanded. The longest digit on the 637 pes is 3.8 in a female.

638

639 Geographic Distribution: The species is known from north central and western Shasta County, 640 California, as well as extreme southeastern Siskiyou County in the vicinity of Castle Crags,

641 California, but the identity of scattered specimens from the western margin of the Sacramento

642 Valley to the south has not been determined. Aneides iecanus occurs at elevations ranging 643 between about $300 \mathrm{~m}$ (near the surface of Lake Shasta) to over $1000 \mathrm{~m}$ (in the Castle Crags 644 area). Populations along the inner margins of the Coast Ranges in western Tehama and Glenn 645 Counties (see map Fig. 5) may be assignable to Aneides iecanus, but further surveys including 646 morphological and genetic analyses are needed.

647

Etymology: The species name was derived from the local Native American word "Iëka," which 649 according to Cope refers to Mount Shasta.

650

Remarks: The type locality, near the old federal fish hatchery on the McCloud River, named 652 Baird, now lies under the waters of the reservoir, Shasta Lake. The species is widespread in the 653 Shasta Lake area, and extends as far north as the Castle Crags area right on the Siskiyou-Shasta 654 county border. Cope either was unaware of the description of $P$. flavipunctatus three years 655 earlier, or of its relatedness to P. iecanus (Cope, 1889, placed the two taxa in different genera). 656 The taxon was synonymized with A. flavipunctatus by Storer (1925). Larson (1980) concluded that populations of A. flavipunctatus from Shasta County were divergent within the flavipunctatus complex. The range of Nei D to other part of the complex are: to klamathensis $0.099-0.149$, to flavipunctatus $0.132-0.209$, and to niger 0.222 . Larson estimated that the Shasta population had first diverged from the rest of the complex nearly 2.6 million years ago. Rissler \& Apodaca (2007) estimated a mtDNA phylogeny that found Shasta 662 County samples to be monophyletic, and sister to samples from the Klamath Mountains. This 663 finding was supported by subsequent mtDNA phylogenies estimated by Reilly et al. (2013) and 664 Reilly \& Wake (2015), which suggested a mtDNA divergence of 4-6.8\% corresponding to a 665 divergence time in the mid-Pleistocene. Population clustering analysis of sequence data from 13 666 nuclear loci also found the Shasta populations to be distinct, with unique derived mutations at 
667 nearly every locus (Reilly et al., 2013). Coalescent analyses of gene flow between Shasta 668 County and the Klamath Mountains populations found $2 \mathrm{Nm}$ values to be less than 1 in both 669 directions, suggesting genetic isolation across the Trinity Mountains ridge separating Shasta and 670 Trinity Counties (Reilly et al., 2013). When a species tree methodology is applied to the 671 mtDNA + nDNA data, populations from Shasta County are recovered as sister to all main range 672 populations (A. flavipunctatus + A. klamathensis). However, a species tree constructed from 673 only nuclear loci is in agreement with Larson's finding that Shasta County populations constitute 674 the basal lineage within the complex (Reilly \& Wake, 2015) (see Fig. 8).

675 The genetic findings outlined above are reinforced by ecological and morphological 676 findings from previous studies that show sharp breaks in microhabitat use, vertebral number, and 677 coloration between Shasta salamanders and the nearest populations within the Klamath 678 watershed to the west. Lowe (1950) considered the Shasta population to be a distinct sub679 species, because they differed from Klamath populations in habitat use and color pattern. 680 Subsequently, Lynch (1974) found that salamanders in Shasta County prefer shaded, streamside 681 habitat, while salamanders in the Klamath watershed prefer exposed, rock talus habitat. 682 Osteologically, Shasta Co. black salamanders average 16 vertebrae while Klamath River 683 watershed black salamanders average 17 vertebrae (Lynch, 1981). With regards to coloration, 684 Shasta Co. black salamanders have a black coloration with numerous small white spots (Fig. 11), 685 while Klamath watershed black salamanders generally retain the juvenile xanthophore pigments 686 into adulthood, which gives them a green, gold, or greyish frosted coloration (Lynch, 1981) (see 687 Fig. 6, 7).

688

\section{Redescription of Aneides flavipunctatus (Strauch 1870)} Plethodon flavipunctatus - Strauch, 1870

691 Aneides flavipunctatus (part) - Storer, 1925

692 Speckled Black Salamander

693

694 Figures $12-15$

695

696 Lectotype: “ZISP 156, “Californien (Neu-Albion)" "Leg: I. G. Wosnessensky, 1843” (Lectotype 697 designated by Miltof and Barabarno, 2011, p. 139; Fig. 14) (original syntypes ZISP 155 [now 
698 lost], ZISP 157). Miltof and Barabarno (2011) interpreted "Neu-Albion" as [Albion, Mendocino

699 County, California, USA].

700

701 Diagnosis: A large (some individuals exceed $80 \mathrm{~mm} \mathrm{SL}$ ) member of the Aneides flavipunctatus 702 complex, subgenus Aneides, distinguished from members of the subgenus Castaneides by larger 703 size (A. aeneus less than $70 \mathrm{SL}$ ), rounded rather than flattened head and body, more robust body 704 and tail, with relative much shorter limbs and digits and blackish rather than greenish coloration. 705 Distinguished from other members of subgenus Aneides as follows: from $A$. hardii by its much 706 larger size (A. hardii less than $60 \mathrm{SL}$ ), more robust head, body and tail, and subdued sexual 707 dimorphism; from the somewhat larger A. lugubris (some individuals exceed $100 \mathrm{~mm} \mathrm{SL}$ ) by 708 darker ground coloration, more robust and less prehensile and tapered tail, and much shorter 709 limbs and digits; from $A$. ferreus and $A$. vagrans by larger size (these species rarely exceed 75

$710 \mathrm{~mm} \mathrm{SL}$ ), more robust and less prehensile and tapered tail, and much shorter limbs and digits.

711 This species is distinguished from other members of the Aneides flavipunctatus as follows: from 712 A. klamathensis in having variable coloration but generally lacking the frosted dorsal coloration, 713 especially in the southern parts of its range, and only a few populations have 17 trunk vertebrae;

714 from $A$. iecanus in it more variable coloration and habitat preferences; from $A$. niger in its more 715 variable coloration but rarely with so few iridophores.

716

717 Description: Aneides flavipunctatus is a large, robust salamander. Reilly and Wake (2015, Fig.

718 3A) recognized two major molecular-based clades, northern (Central Core, Clade 1) and a

719 southern (Central Core, Clade 2) groups of populations. Lynch (1981) presented information on

720 mean SL and possible sexual dimorphism for relatively large samples of full adults from

721 populations representing each clade, as follows: Clade 1: Lynch population 001 (Salmon Point), 722 M 65, F 68; Population 007 (McGuire Hill), M 65.4, F 69 (statistically significant difference);

723 Population 158 (Leggett), M 74.7, F 69.2; Population 161 (Usal) M 70.9, F 68.8; Population 187

724 (Alderpoint), M 72.8, F 70.9. Clade 2: Population 010 (Navarro), M 69.3, F 66.7; Population

725055 (Skaggs Springs) M 64.4, F 63.7; Population 063 \& 070 (Guerneville) M 68.5, F 68.1;

726 Population 111 (Potter Valley), M 64.1; F 63.6; Population 121 (Geyserville), M 71.1, F 64.5

727 (statistically significant difference). We measured samples of large adults selected from

728 populations in the heart of the respective ranges and obtained values of SL, as follows. Clade 1:

Peer] reviewing PDF | (2019:04:36410:1:1:NEW 22 Jun 2019) 
$72964.4-80.3$. mean $72.8+/-5.0$ for 10 males; $67.2-78.1$, mean $71.2+/-3.2$ for 11 females.

730 Clade 2: 64.0 - 71.7, mean $68.0+/-2.6$ for 10 males; $63.3-69.9$, mean $66.6+/-2.1$ for 10

731 females. As in other members of this complex, heads are large and laterally expanded behind the

732 eyes in both sexes but especially so in large males. Head width for the Clade 1 sample of 10

733 males is $10.4-15.2$, mean $11.9+/-1.4(0.13-0.16$, mean $0.15+/-0.01$ times SL); 11 females

7348.9 - 11.8 mean $10.8+/-0.98$ (0.13 - 0.16, mean 0.15+/- 0.01 times SL); for Clade 2 sample of

73510 males is $10.3-11.7$, mean $11.1+/-2.6(0.15-0.18$, mean $0.16+/-0.03$ times SL); 10

736 females $92-11.1$, mean $10.0+/-0.65(0.14-0.16$, mean $0.15+/-0.01$ times SL). The strong

737 jaws bear few maxillary and mandibular teeth, but the longest one to three teeth are very large.

738 Limbs are moderately long and robust. Combined limb length (CLL) for the Clade 1 sample of

73910 males is $32.3-36.8$, mean 34.9; CLL/SL $0.45-0.49$, mean $0.47+0.02$; 11 females $31.0-$

740 35.5, mean 33.0+/- 1.5; CLL/SL 0.42 - 0.48, mean 0.46+/- 0.02; for Clade 2 sample of 10

741 males 29.1 - 31.9, mean 30.2+/- 0.41; for 10 females is $27.4-31.4$, mean 29.3+/- 1.3. Limb

742 interval for Clade 1 is 1 - 3, mean 2.6 +/- 0.6 for 10 males; 2- 4, mean 3.2 +/- 0.3 for 11 females;

743 for Clade 22 - 3, mean $2.25+/-0.95$ in 10 males; 2.5 - 4, mean $3+/-0.4$ in 10 females. Tails

744 are robust and moderately long but most show signs of regeneration. The longest tails reach SL

745 in males and SL in females. Digits are long and slender, and are terminally expanded. The

746 longest digit on the pes for Clade 1 males is 3.5 and 4.5 in a female; for Clade 2 males 3.2 and

7474.9 in a female (females generally have longer digits).

748

749 Geographic distribution: From northern Sonoma and Napa counties north into southern

750 Humboldt County near Cape Mendocino and Larabee Creek, east to the interior edge of the coast

751 ranges. As mentioned above, populations along the inner margins of the Coast Ranges in

752 western Tehama and Glenn Counties (see map Fig. 5) are of unknown status, and further surveys

753 including morphological and genetic analyses of these populations are needed to confirm their

754 taxonomic designation.

755

756 Etymology: Strauch (1870) offered no explanation for his name, but presumably he assumed

757 that the light spots then still evident in the types were yellowish, rather than whitish or cream-

758 colored (the true color) in life.

759 
760 Remarks: In previous comparison sections we have summarized the results of Larson's (1980)

761 allozyme study and presented Nei genetic distances to Aneides flavipunctatus. The greatest

762 value of Nei D is 0.209 to A. iecanus; all other values are 0.182 or less. Among population

763 levels within A. flavipunctatus range from 0.023 to 0.117 . These distances are not as great as

764 one might expect based on the high degree of divergence within A. flavipunctatus in DNA

765 (Reilly \& Wake, 2015). The allopatry of A. flavipunctatus, A. niger and A. iecanus assures that

766 the three taxa are readily distinguished, but it is difficult if not impossible to distinguish living $A$.

767 flavipunctatus and A. klamathensis in the inland portions of their contact zone. The very detailed

768 study of coloration and morphology by Lynch (1981) documents the great variation within $A$.

769 flavipunctatus (see Fig. 1, 12) while at the same time making clear that while A. klamathensis is

770 distinguishable from most A. flavipunctatus by general color pattern and by details of coloration,

771 where the ranges of the two approximate each other it can be difficult to separate the two. A

772 genomic approach is likely needed to fully understand the dynamics of the southern Humboldt

773 contact zone.

774 A detailed itinerary of the collector of the types, I. G. Voznesenskii, is available in

775 Alekseev (1987). We go into some detail in following Voznesenskii's travels because it is

776 important to try to identify the type locality, given the very extensive genetic substructuring of

777 clade 2 of our revised Aneides flavipunctatus. He arrived in present-day Bodega Bay, about 18

778 miles $(29 \mathrm{~km})$ south of the Fort Ross settlement, on July 20, 1840, and slowly made his way

779 north, collecting along the way. He visited the Russian Chernykh and Kostromitinov ranches,

780 south of the "Slavianka" River (present-day Russian River), and reached Fort Ross in mid-

781 August, 1840. The fort was then in its last days, a decision having been made in 1839 to

782 abandon it (the land and much equipment was sold to the American John Sutter). Voznesenskii

783 did not spend much time at the fort, but took excursions northward (as far as Cape Mendocino)

784 and inland. He packed 13 crates and two kegs with materials to be returned to Russia and

785 shipped them from San Francisco in October, 1840. Apparently, the salamanders in question

786 were not a part of that collection, because they did not reach the Museum in St. Petersburg until

7871843 (Milto \& Barabanov, 2011). He spent a lot of time in late 1840 and the spring of 1841 in

788 and around San Francisco Bay. From mid-April through May and June, 1841, he traveled the

789 length of the Russian River and surrounding area, and on June $16^{\text {th }}$ he became the first westerner

790 to climb Mt. St. Helena (which he named, for the wife of the manager of Fort Ross, Yelena 
791 Rocheva, an admirable woman but no saint; he left a plate of copper to commemorate the event,

792 which was later found). In July, 1841, Fort Ross was abandoned and he spent the remaining time

793 awaiting transport to Sitka (he departed Sept. 5, 1841) at another Russian ranch, the Khlebnikov

794 Ranch inland from the present town of Bodega, probably near present-day Occidental. Details of

795 collection of the specimens are not given, but the specimens are described by Strauch (1870) as

796 having many relatively large spots (which were thought to be yellowish by Strauch, but in life

797 are whitish). We know that more inland populations have larger spots than coastal populations.

798 We assume the specimens were part of the shipment that accompanied the party as it went to

799 Sitka. Voznesenskii was delayed in making his next shipment to Russia until he returned from a

800 trip to present-day Baja California sometime after March, 1842. This is the shipment that

801 probably reached Russia in 1843.

802 We think the type specimens were collected in or near the Russian River valley region in

803 the spring of 1841. Lynch's (1981) detailed color analysis shows that populations with the most

804 abundant large spots occur inland in northeastern Sonoma and southeastern Mendocino counties.

805 By mid-May salamander activity would have declined, and by June when Mt. St. Helena was

806 climbed Voznesenskii describes the area around Santa Rosa as having the nature of a desert (it

807 does not, but does dry rapidly through May and June, when typically almost no rain falls). The

808 types likely occur within the "Central Core, Clade 2" of Reilly and Wake (2015, Fig. 3), possibly

809 either within the Lake Berryessa (LB) or the Sonoma (SON) subclades. Both have large,

810 numerous white spots and lie within the Russian River Valley region. Figure 13 shows a series

811 of A. flavipunctatus from the Russian River Valley in Sonoma County, and most individuals

812 exhibit large white spots. Figure $12 \mathrm{~d}$ and $12 \mathrm{e}$ show two A. flavipunctatus that exhibits spots

813 from just east and west (respectively) of Geyserville in the Russian River Valley. In fact, SON

814 extends to the coast very near Fort Ross (where, however, the spots are relatively subdued).

815 Storer (1925) suggest the type locality was in Sonoma County and we agree. Subsequently (as in

816 Milto \& Barabanov 2011) "neu-Albion” has been interpreted as "Albion", a coastal village well

817 to the north of Fort Ross, but that place did not exist in 1841 and restriction of the type locality to

818 that site is unwarranted. Both the lectotype (Fig. 14a) and paralectotype (Fig. 14b) have lost

819 their coloration and are thus unable to give us a sense of the number or size of spots.

820 Of the now four members of the Aneides flavipunctatus complex, A. flavipunctatus is the

821 most widespread and by far the most internally variable with respect to all variables studied. 
822 Lynch (1981) showed extensive variation in coloration, coloration ontogeny, morphology, and

823 trunk vertebral numbers which vary from 15 to 18 with means ranging between 16 and 17 .

824 Reilly and Wake (2015) showed that molecular traits measured also vary substantially and

825 recognized two main clades based on nuclear DNA, in the far northern part of the range and then

826 through the rest of the range to the south and east. Within the northern clade (1) 8 distinct

827 mtDNA clades were identified, with 3 (two of which were relatively highly differentiated

828 internally) in the southern clade (2). In contrast, $3 \mathrm{mtDNA}$ clades were reported in $A$.

829 klamathensis but only one each in A. iecanus and A. niger. A sharply defined molecular break

830 separates the two clades of A. flavipunctatus in the Longvale/Laytonville region of Mendocino

831 Co. where coloration is highly variable (Fig. 15). Future research should focus on this

832 complicated contact zone (Reilly et al., 2012; Reilly \& Wake, 2015, Fig. 3), where, however,

833 nuclear and mtDNA borders do not coincide. Phylogenomic data are likely needed to fully

834 understand the variation present within A. flavipunctatus.

835

836 Conservation Concerns

837

838 The most vulnerable of the four species of the Aneides flavipunctatus complex are A. niger and

839 A. iecanus. Both have relatively small geographic ranges within which critical habitat has been

840 heavily impacted by humans (discussed below). In contrast, A. flavipunctatus and $A$.

841 klamathensis occur over large regions and our recent observations indicate that both are wide-

842 spread within their ranges and that they are locally abundant, with relatively dense populations.

843 We consider them to be of no particular concern from a conservation perspective. Recent survey

844 work has expanded the range limits of this complex and other plethodontid salamanders in the

845 region, and we suggest further surveys of the black salamander complex (e.g. Olson, 2008;

846 Reilly et al., 2010; Lindstrand et al., 2012). Genetically and morphologically distinct

847 populations (especially as we have reported for segments of $A$. flavipunctatus) might best be

848 treated as management units (or ESUs) and periodically monitored and surveyed.

849 In general, A. iecanus is found at elevations below 600 meters (Lynch, 1981) around

850 Shasta Lake and adjacent areas (as far south as Castle Crags), usually in the vicinity of creeks

851 and in local canyons (Fig. S1). The initial creation of the Shasta Dam and reservoir reduced the

852 range of this species by flooding much of the most suitable habitat in Shasta County. The 
853 proposed raising of Shasta Dam would result in the flooding of much of the remaining low 854 elevation habitat around the lake where A. iecanus is currently most abundant (Fig. S1).

855 Flooding of this prime habitat and the associated construction/road building activity will have 856 severe negative impacts on this and other sensitive species (e.g. Hydromantes web-toed 857 salamanders). Because genetic diversity within this species is low compared to A. flavipunctatus 858 and A. klamathensis (Reilly \& Wake, 2015) special attention should be focused on protecting this 859 genetic diversity and maintaining connectivity between genetically distinct populations.

Several workers have recorded that $A$. niger has experienced population declines over the 861 past decades. Members of this once-abundant species have become difficult to find when 862 compared to historical descriptions of its abundance (e.g., Van Denburgh, 1895; cf. Stebbins

863 2003), which may be due to a number of factors including habitat disturbance and destruction 864 (especially along small seeps and creeks), disease (such as pathogenic fungi), and climate 865 change. Aneides niger already occurs at the southern extent of the range of the black salamander complex in the Santa Cruz Mountains, which are relatively hotter and drier than the rest of the complex's range. Genetic diversity within this species is also low when compared to $A$. flavipunctatus and A. klamathensis (Reilly \& Wake, 2015) and the protection of genetic diversity within this species should be part of any conservation plan. Aneides niger (or A. f. niger at the time) is listed as a Priority 3 Species of Special Concern by the California Department of Fish and Wildlife and a detailed treatment of the species can be found in Thomson et al. (2016).

Additional survey work is critically needed for both $A$. niger and A. iecanus to determine their current distribution, estimate actual census population sizes, and determine the level of

874 protection needed to ensure long-term persistence. If it is judged that adequate data concerning 875 these taxa and their biological status exist, we suggest the following categories of threat using 876 IUCN guidelines (IUCN 2012): Aneides flavipunctatus Least Concern (LC); Aneides iecanus 877 Vulnerable (Vu), based on criteria A1, B1b; Aneides klamathensis Least Concern (LC); Aneides 878 niger Vulnerable (Vu), based on criteria A1, B1b.

\section{Conclusion}

881

882 For many years the taxonomy of the Aneides flavipunctatus complex has been in a state of flux, 883 with taxonomic proposals ranging from a single species with no subspecies (Lynch, 1981) to 
884 Rissler and Apodaca (2007), who suggested that four taxa were justified by their data but who 885 took no formal action. For some years we have devoted our efforts to increasing the scope of the 886 study of this complex by adding new data and greatly expanding the geographic extent of the 887 study. We conclude that four taxa are warranted by the data, and have named one new species, 888 raised the rank of one taxon, and removed one taxon from synonymy. However, the remaining 889 A. flavipunctatus is a heterogeneous entity that is highly differentiated in all measured traits. 890 Future studies may find justification for additional taxa.

891

\section{Acknowledgments}

893

894 We dedicate this paper to the memory of two individuals, both deceased, who conducted their 895 doctoral thesis research on the Aneides flavipunctatus complex but came to different conclusions: 896 Charles H. Lowe, Jr. and James F. Lynch. We are grateful to Mitchell Mulks who helped with 897 field collections and photography of specimens. We thank Andrew Gottscho, Jon Hirt, Jason 898 Reilly, and many others who helped with the collection of specimens and tissues. SBR thanks 899 Barry Sinervo, W. Bryan Jennings, Sharyn Marks, and Jimmy A. McGuire for their support and 900 help in the development of this study. Lydia Smith and the Evolutionary Genetics Laboratory at

901 UC Berkeley provided laboratory support, Michelle Koo gave GIS support and thoughtful 902 discussions, Sean Rovito helped with morphological analyses, and Carol Spencer facilitated 903 museum accessions and loans.

904

905

\section{References}

906

Alekseev AT. 1987. The odyssey of a Russian scientist: I. G. Voznesenskii in Alaska, California 908 and Siberia 1839 - 1849. Kingston, Ontario, Canada: The Limestone Press (translated from a Russian language ms).

910 Bingham RE, Papenfuss TJ, Lindstrand L, Wake DB. 2018. Phylogeography and species

911 boundaries in the Hydromantes shastae complex, with description of two new species

912 (Amphibia; Caudata; Plethodontidae). Bulletin of the Museum of Comparative Zoology

913 161:403-428 https://doi.org/10.3099/MCZ42.1.

914 Collins JT, Taggart TW. 2002. Standard common and current scientific names for North 
915

916

917

918

919

920

921

922

923

924

925

926

927

928

929

930

931

932

933

934

935

936

937

938

939

940

941

942

943

944

945

American amphibians, turtles, reptiles \& crocodilians. Lawrence, Kansas: Center for North American Herpetology.

Cope ED. 1869. A review of the species of Plethodontidae and Desmognathidae. Proceedings of the Academy of Natural Sciences of Philadelphia 21:93-118.

Cope ED. 1883. Notes on the geographical distribution of Batrachia and Reptilia in western North America. Proceedings of the Academy of Natural Sciences of Philadelphia 35:10-35.

Cope ED. 1886. Synonymic list of the North American species of Bufo and Rana, with descriptions of some new species of Batrachia, from specimens in the National Museum. Proceedings of the American Philosophical Society 23:514-526.

Cope ED. 1889. The Batrachia of North America. United States National Museum Bulletin $34: 1-523$.

Dubois A, Raffaelli J. 2012. A new ergotaxonomy of the order Urodela Dumeril, 1805 (Amphibia, Batrachia). Alytes 28:77-161.

Edgar RC. 2004. MUSCLE: multiple sequence alignment with high accuracy and high throughput. Nucleic Acids Research 32:1792-1797 https://doi.org/10.1093/nar/gkh340.

Fowler HW, Dunn ER. 1917. Notes on salamanders. Proceeding of the Academy of Natural Sciences of Philadelphia 69:7-28.

Grinnell J, Camp CL. 1917. A distributional list of the amphibians and reptiles of California. University of California Publications in Zoology 17:127-208.

Hallowell, E. 1849. Description of a new species of salamander from Upper California. Annals and Magazine of Natural History 4:76-77.

Highton R. 2000. Detecting cryptic species using allozyme data. In The biology of plethodontid salamanders (pp. 215-241). Springer, Boston, MA.

IUCN Species Survival Commission. 2012. IUCN Red List categories and criteria, Version 3.1, Second edition. Gland, Switzerland, IUCN.

Kearse M, Moir R, Wilson A, Stones-Havas S, Cheung M, Sturrock S, Buxton S, Cooper A, Markowitz S, Duran C, Thierer T, Ashton B, Mentjies P, Drummond A. 2012.

Geneious Basic: an integrated and extendable desktop software platform for the organization and analysis of sequence data. Bioinformatics 28:1647-1649 https://doi.org/10.1093/bioinformatics/bts199.

Larson A. 1980. Paedomorphosis in relation to rates of morphological and molecular 
946

947

948

949

950

951

952

953

954

955

956

957

958

959

960

961

962

963

964

965

966

967

968

969

970

971

972

973

974

975

976

evolution in the salamander Aneides flavipunctatus. Evolution 34:1-17

https://doi.org/10.1111/j.1558-5646.1980.tb04785.x.

Lindstrand III L, Bainbridge K, Youngblood G. 2012. Habitat characteristics, a range extension, and an elevational record for Shasta salamanders. California Fish and Game 98:236-241.

Lowe CH. 1950. Speciation and ecology in salamanders of the genus Aneides. Ph.D. dissertation, University of California, Los Angeles, CA.

Lynch JF. 1974. Aneides flavipunctatus. Catalogue of American Amphibians and Reptiles, 158:1-2.

Lynch JF. 1981. Patterns of ontogenetic and geographic variation in the black salamander, Aneides flavipunctatus. Smithsonian Contributions to Zoology 324:1-53.

Milto KD, Barabanov AV. 2011. An annotated catalogue of the amphibian types in the collection of the Zoological Institute, Russian Academy of Sciences, St. Petersburg. Russian Journal of Herpetology 18:137-153.

Myers GS, Maslin TP. 1948. The California plethodont salamander, Aneides flavipunctatus (Strauch): with description of a new subspecies and notes of other western Aneides. Biological Society of Washington 61:127-128.

Olson DH. 2008. Conservation assessment for the Black Salamander (Aneides flavipunctatus) in Oregon. U.S.D.A. Forest Service Region 6 and U.S.D.I. Bureau of Land Management, Interagency Special Status and Sensitive Species Program, 1-23.

Posada D. 2008. jModelTest: Phylogenetic Model Averaging, Molecular Biology and Evolution 25:1253-1256 https://doi.org/10.1093/molbev/msn083.

R Core Team. 2018. R: A language and environment for statistical computing. R Foundation for Statistical Computing, Vienna, Austria. Available at www.R-project.org.

Reilly SB, Gottscho AD, Garwood JM, Jennings WB. 2010. Phylogenetic analysis of common garter snake (Thamnophis sirtalis) stomach contents detects cryptic range of a secretive salamander (Ensatina eschscholtzii oregonensis). Herpetological Conservation and Biology 5:395-402.

Reilly SB, Marks SB, Jennings WB. 2012. Defining evolutionary boundaries across parapatric ecomorphs of black salamanders (Aneides flavipunctatus) with conservation implications. Molecular Ecology 21:5745-5761 https://doi.org/10.1111/mec.12068. 
977 Reilly SB, Mulks MF, Reilly JM, Jennings WB, Wake DB. 2013. Genetic diversity of black

978

979

980

981

982

983

984

985

986

987

988

989

990

991

992

993

994

995

996

997

998

999

1000

1001

1002

1003

1004

1005

1006

salamanders (Aneides flavipunctatus) across watersheds in the Klamath Mountains.

Diversity 5:657-679 https://doi.org/10.3390/d5030657.

Reilly SB, Wake DB. 2015. Cryptic diversity and biogeographical patterns within the black salamander (Aneides flavipunctatus) complex. Journal of Biogeography 42:280-291 https://doi.org/10.1111/jbi.12413.

Rissler LJ, Apodaca JJ. 2007. Adding more ecology into species delimitation: ecological niche models and phylogeography help define cryptic species in the black salamander (Aneides flavipunctatus). Systematic Biology 56:924-942 https://doi.org/10.1080/10635150701703063.

Stamatakis A. 2014. RAxML version 8: a tool for phylogenetic analysis and post-analysis of large phylogenies. Bioinformatics 30:1312-1313 https://doi.org/10.1093/bioinformatics/btu033.

Stebbins, RC. 1951. Amphibians of western North America. Berkeley, Ca, University of California Press.

Stebbins RC. 2003. A field guide to western reptiles and amphibians. Third edition. Boston, Houghton Mifflin Company.

Storer TI. 1925. A synopsis of the amphibia of California. Vol. 27. University of California Publications in Zoology 27:1-342.

Strauch A. 1870. Revision der Salamandriden-Gattungen nebst beschreibung einiger neuen und weniger bekannten Arten dieser Familie. Memoires de l'Academie Imperiale des Sciences de St. Petersbourg 16:1-110.

Thomson RC, Wright AN, Shaffer HB. 2016. California Amphibian and Reptile Species of Special Concern. University of California Press, Oakland, California.

Van Denburgh J. 1895. Notes on the habits and distribution of Autodax iecanus. Proceedings of the California Academy of Sciences 5:776-778.

Venables WN, Ripley BD. 2002. Modern Applied Statistics with S. Fourth edition. New York: Springer.

Wake DB. 1963. Comparative osteology of the plethodontid salamander genus Aneides. Journal of Morphology 113:77-118 https://doi.org/10.1002/jmor.1051130106.

Peer] reviewing PDF | (2019:04:36410:1:1:NEW 22 Jun 2019) 
1007 Wake DB. 2016. Persistent plethodontid themes: species, phylogenies, and biogeography.

1008 Herpetologica 73:242-251 https://doi.org/10.1655/HERPETOLOGICA-D-16-00065.1. 


\section{Table 1 (on next page)}

Voucher numbers and localities for newly collected Aneides samples from southeastern Humboldt County.

The locality numbers refer to Figure 2 . 


\begin{tabular}{|c|c|c|c|c|c|c|c|}
\hline Museum \# & Collector \# & Sex & County & Lat & Long & Haplotype Group & Locality \# \\
\hline MVZ:Herp:272722 & DBW 6645 & F & Humboldt & 40.19155 & -123.58872 & A. flavipunctatus & 3 \\
\hline MVZ:Herp:272723 & DBW 6646 & juv & Humboldt & 40.19155 & -123.58872 & A. flavipunctatus & 3 \\
\hline MVZ:Herp:272724 & DBW 6647 & F & Humboldt & 40.19155 & -123.58872 & A. flavipunctatus & 3 \\
\hline MVZ:Herp:272725 & DBW 6648 & M & Humboldt & 40.20833 & -123.59608 & A. flavipunctatus & 5 \\
\hline MVZ:Herp:272726 & DBW 6649 & M & Humboldt & 40.22648 & -123.60881 & A. flavipunctatus & 6 \\
\hline MVZ:Herp:272727 & DBW 6650 & M & Humboldt & 40.22648 & -123.60881 & A. flavipunctatus & 6 \\
\hline MVZ:Herp:272728 & DBW 6651 & F & Humboldt & 40.26458 & -123.62753 & A. klamathensis sp. nov. & 7 \\
\hline MVZ:Herp:272729 & DBW 6652 & M & Humboldt & 40.26458 & -123.62753 & A. klamathensis sp. nov. & 7 \\
\hline MVZ:Herp:272730 & DBW 6653 & F & Humboldt & 40.26458 & -123.62753 & A. klamathensis sp. nov. & 7 \\
\hline MVZ:Herp:272731 & DBW 6654 & F & Humboldt & 40.30816 & -123.65466 & A. klamathensis sp. nov. & 8 \\
\hline MVZ:Herp:272734 & DBW 6657 & M & Humboldt & 40.33452 & -123.67963 & A. klamathensis sp. nov. & 9 \\
\hline MVZ:Herp:272735 & DBW 6658 & M & Humboldt & 40.33452 & -123.67963 & A. klamathensis sp. nov. & 9 \\
\hline MVZ:Herp:272736 & DBW 6659 & M & Humboldt & 40.33452 & -123.67963 & A. klamathensis sp. nov. & 9 \\
\hline MVZ:Herp:272737 & DBW 6660 & juv & Humboldt & 40.33452 & -123.67963 & A. klamathensis sp. nov. & 9 \\
\hline MVZ:Herp:272738 & DBW 6661 & M & Humboldt & 40.33452 & -123.67963 & A. klamathensis sp. nov. & 9 \\
\hline MVZ:Herp:272740 & DBW 6663 & F & Humboldt & 40.34788 & -123.71286 & A. klamathensis sp. nov. & 10 \\
\hline MVZ:Herp:272741 & DBW 6664 & juv & Humboldt & 40.38870 & -123.74288 & A. klamathensis sp. nov. & 11 \\
\hline MVZ:Herp:272742 & DBW 6665 & M & Humboldt & 40.41800 & -123.76150 & A. klamathensis sp. nov. & 12 \\
\hline
\end{tabular}




\section{Figure 1}

Three contrasting color morphologies found within the Aneides flavipunctatus complex.

(a) The pure black morph is characteristic of Aneides niger and southern coastal populations of Aneides flavipunctatus, and this individual is from near Fort Bragg, Mendocino Co., CA. (b) The frosted morph is characteristic of Aneides klamathensis and can also be found in northern populations of Aneides flavipunctatus; this individual is from near Scotia, Humboldt Co. CA (population 14 in Figure 2). (c) The spotted morph is characteristic of Aneides iecanus (although with smaller and more numerous spots than in this specimen) and southern inland populations of Aneides flavipunctatus; this individual was found near Boonville, Mendocino Co., CA. All of these salamanders are from the range of the revised A. flavipunctatus, illustrating the high degree of color pattern variation present within the species. (photo: D. Portik) 


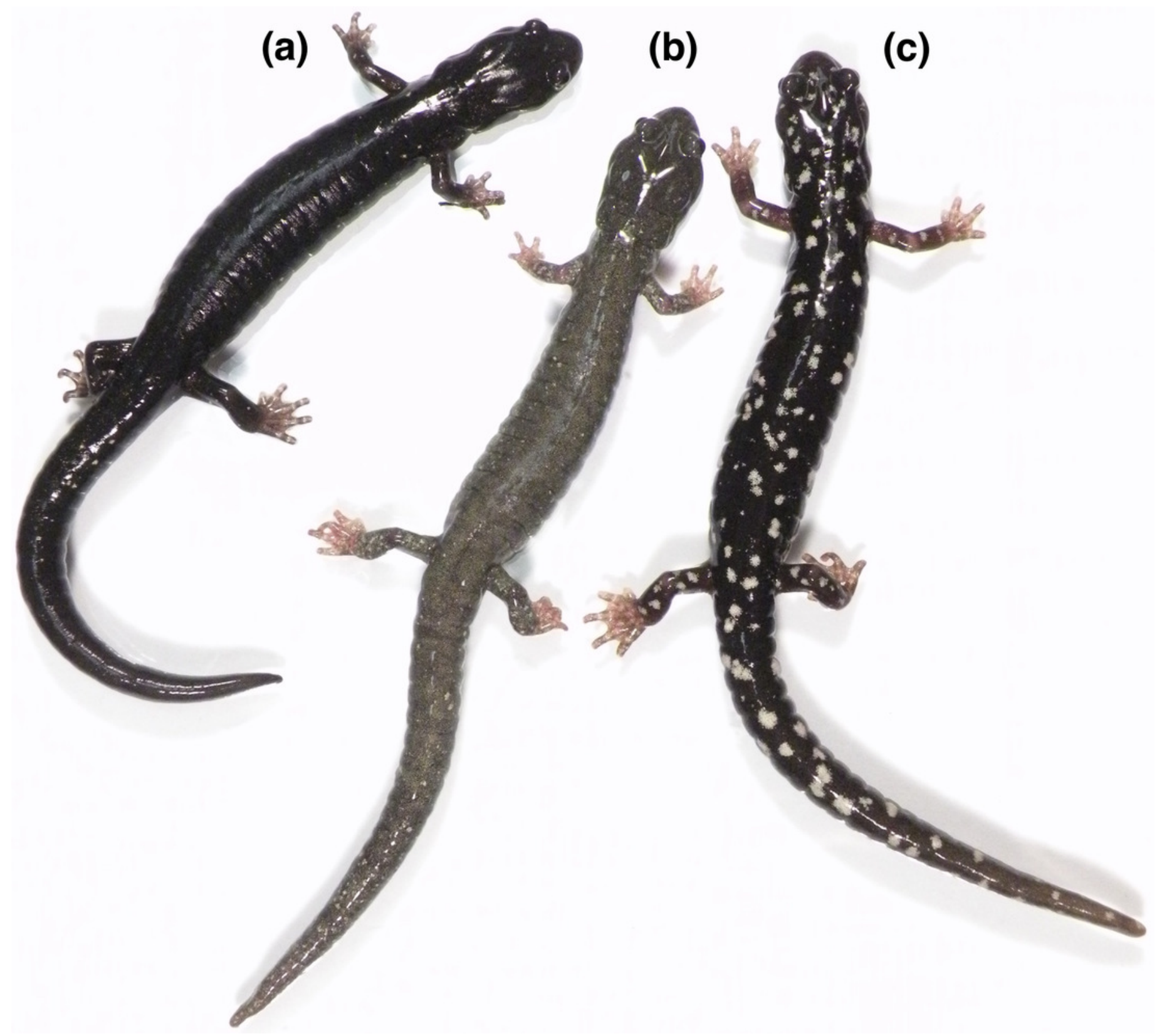




\section{Figure 2}

Map of sample localities from the southern Humboldt County contact zone.

Aneides flavipunctatus $=$ yellow circles; Aneides klamathensis $=$ red squares. Greener shades represent lower elevations and white to brown colors represent higher elevations. Locality numbers are for new samples in this study (see Table 1).

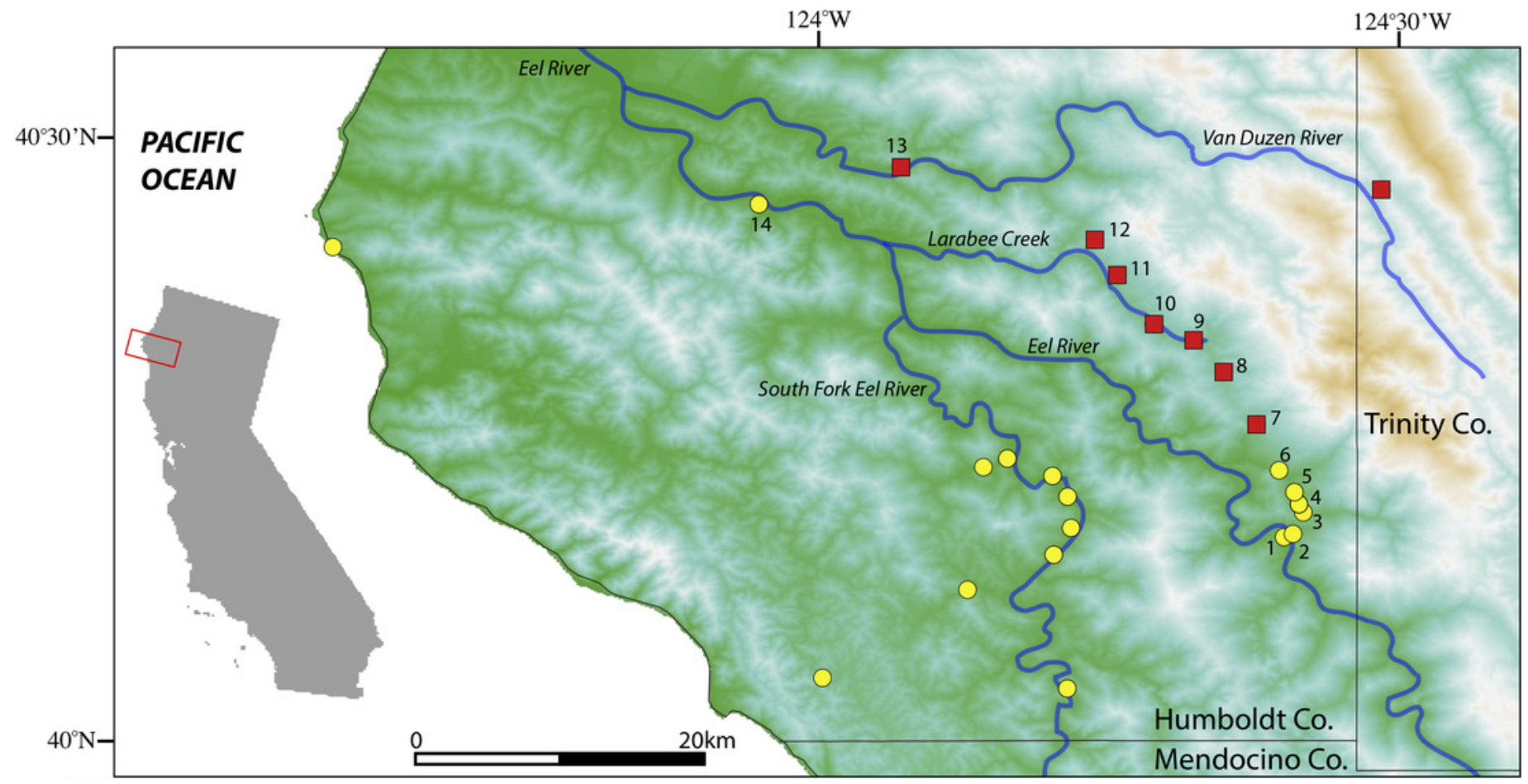


Figure 3 (on next page)

Maximum Likelihood phylogeny of the mitochondrial ND4 gene.

Newly sampled sequences from the Southern Humboldt contact zone are denoted by an asterisk. Bold numbers after the specimen number refer to locality numbers in Figure 2.

Localities 13 and 14 are nearby sites for $A$. klamathensis and $A$. flavipunctatus, respectively. 


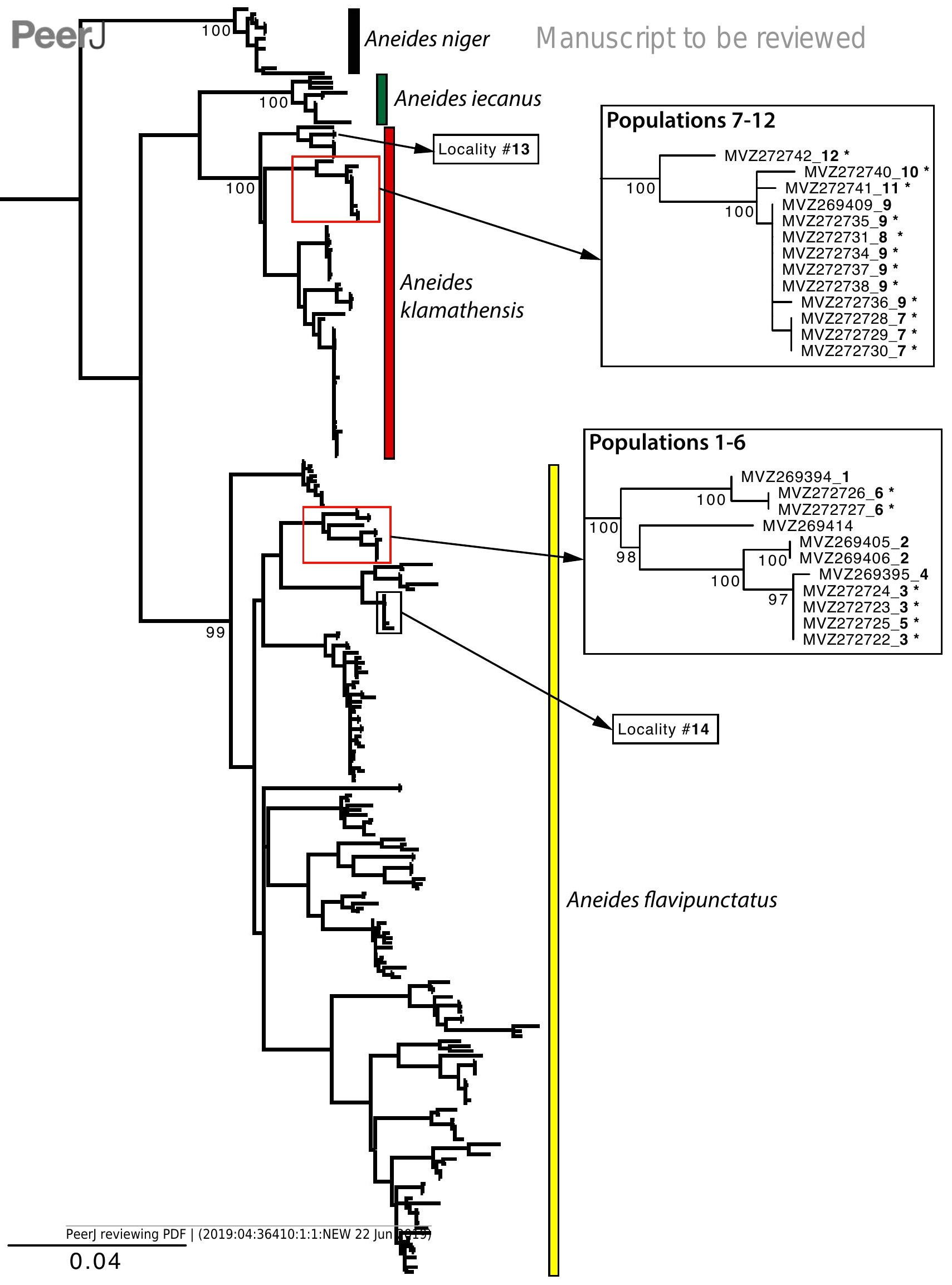


Figure 4 (on next page)

Linear discriminant function analyses of 11 log transformed morphometric measurements.

LD1 plotted against LD2 for (a) males and (b) females. $A f=$ Aneides flavipunctatus; $A k=$ Aneides klamathensis; $A i=$ Aneides iecanus; $A n=$ Aneides niger . 
(a) Males

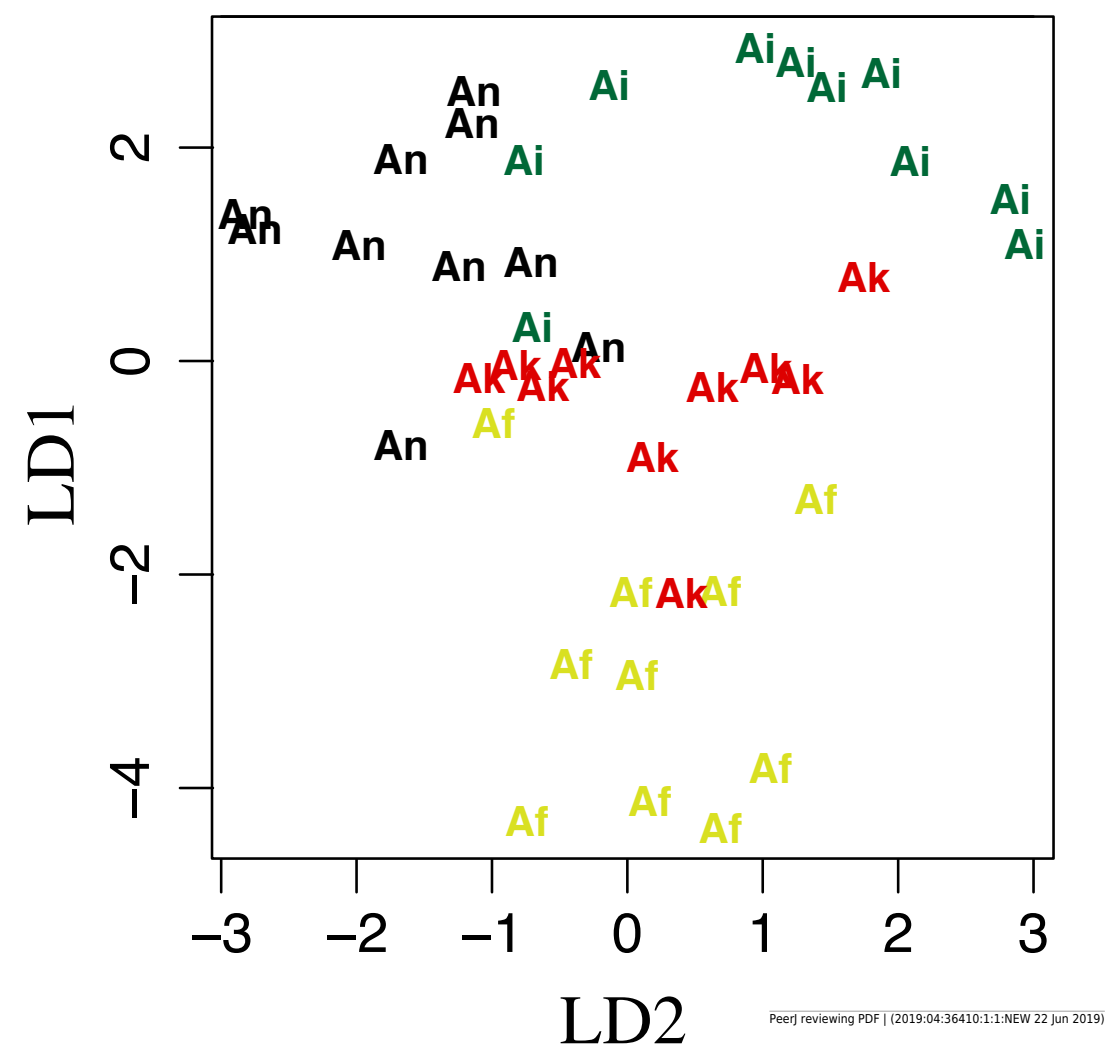

(b) Females

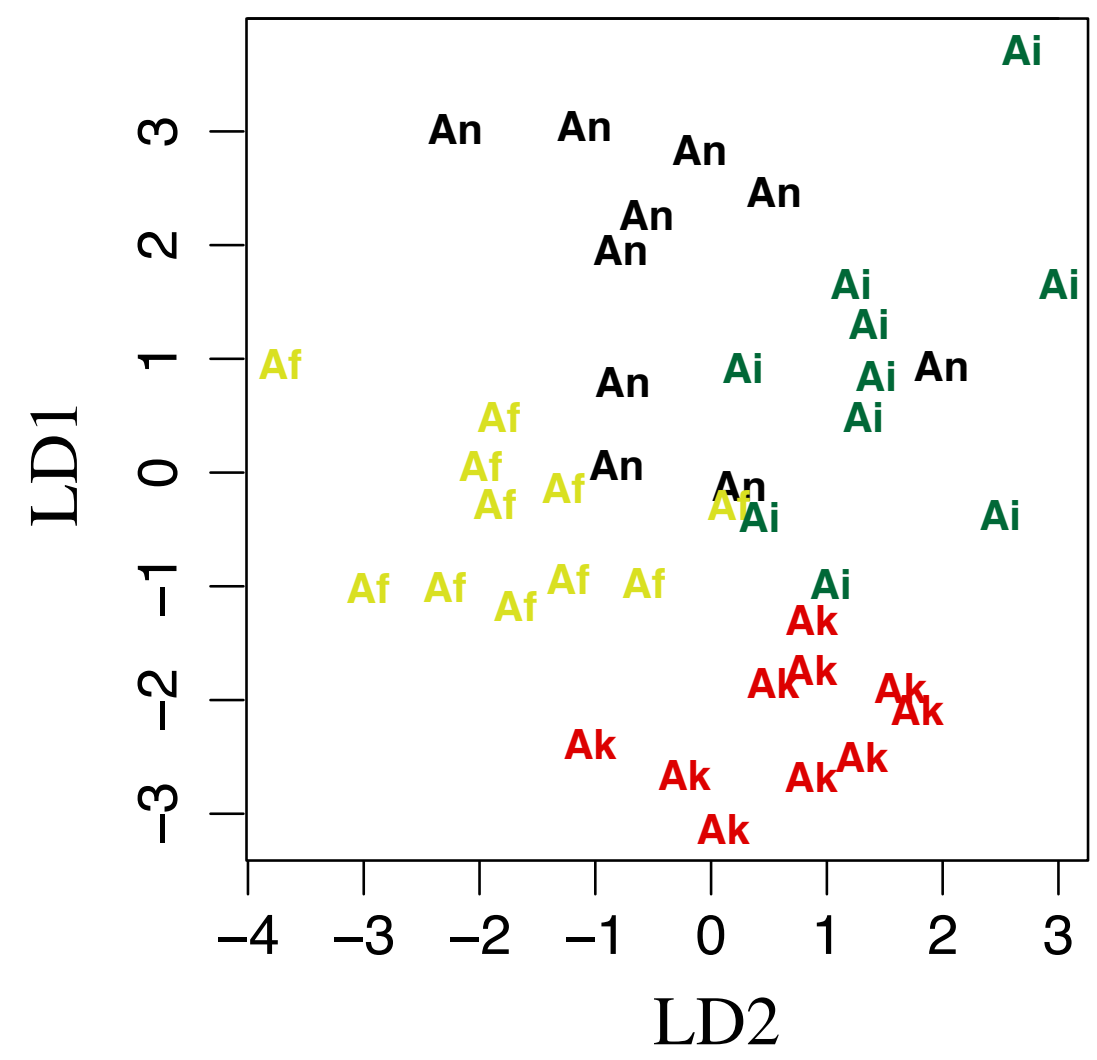


Figure 5

Distribution of the four species comprising the Aneides flavipunctatus complex.

Known type localities for three species shown in red symbol. Type locality of $A$. flavipunctatus likely in northern Sonoma Co. (see text for detailed discussion). Asterisks represent black salamander localities that are of unknown species origin. 


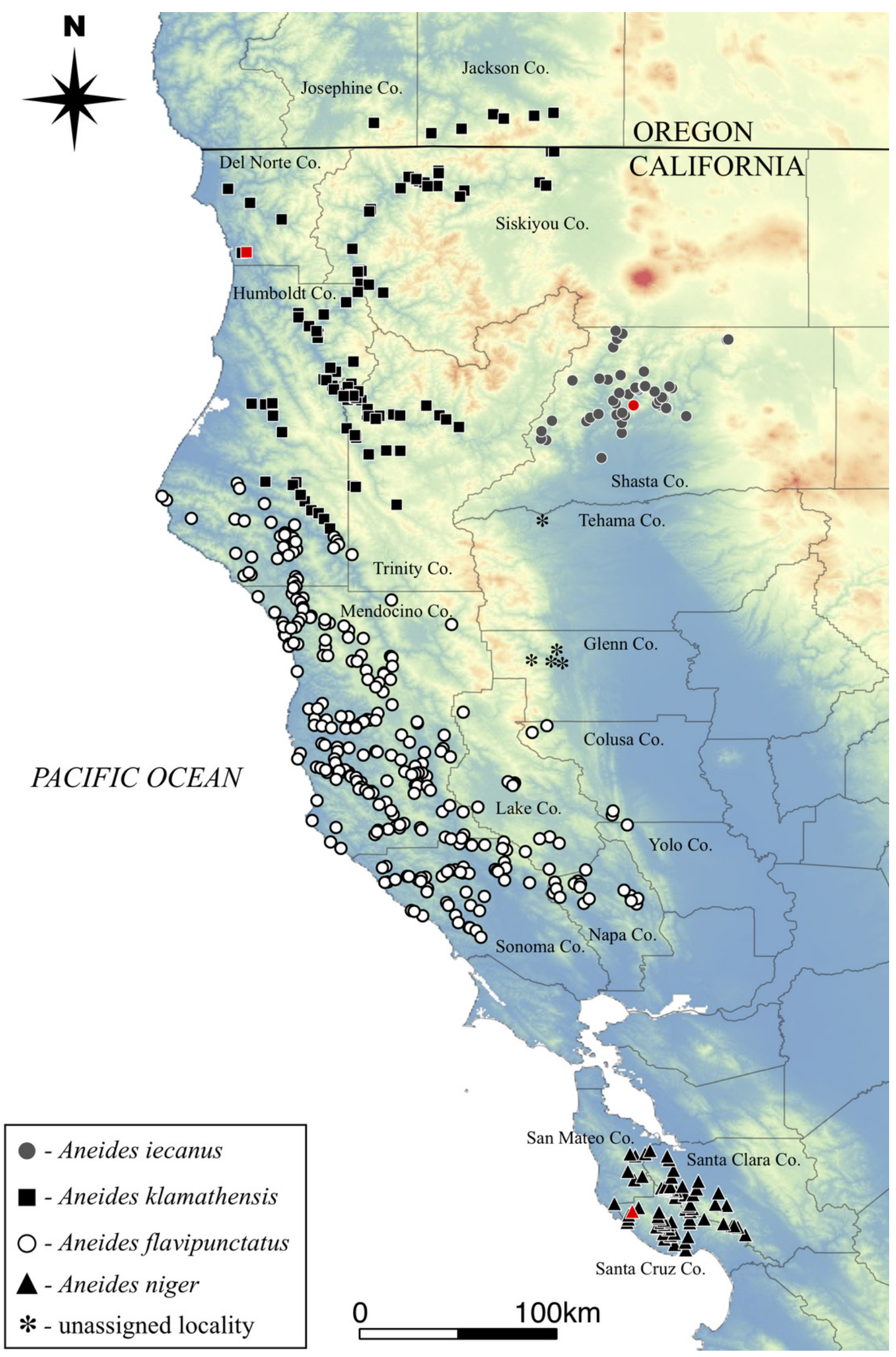




\section{Figure 6}

Holotype of Aneides klamathensis, MVZ 291759, and adult male, photographed in life.

(a) View from the side, (b) dorsal view showing the solid black ground color overlain by greenish-gray pigment that extends partially down the lateral flank of the trunk, and (c) closeup of the rear showing the scattered cream-colored spots that are most numerous on the limbs but relatively few on other dorsal surfaces (photos: M. Mulks). 


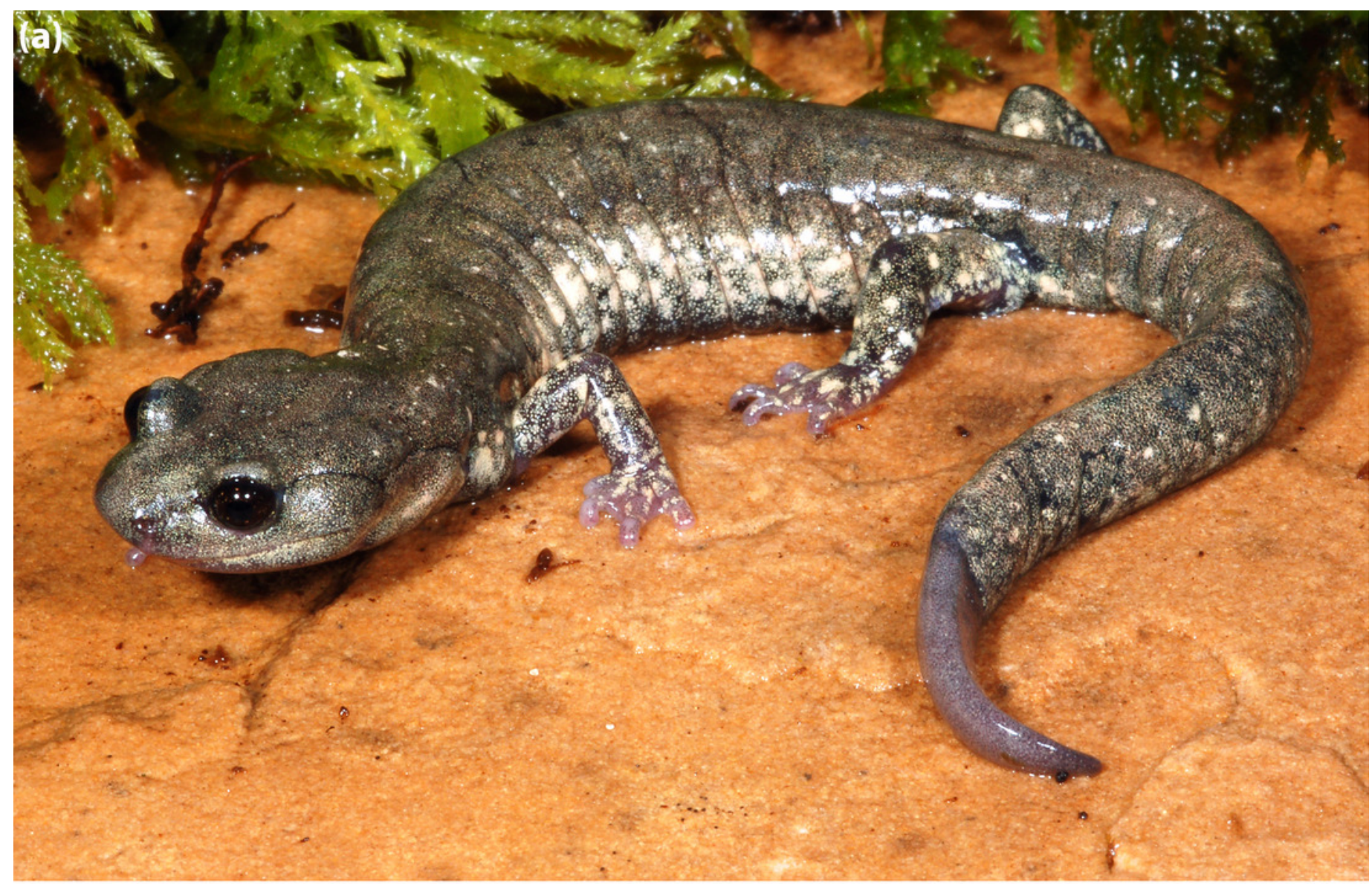

(b)

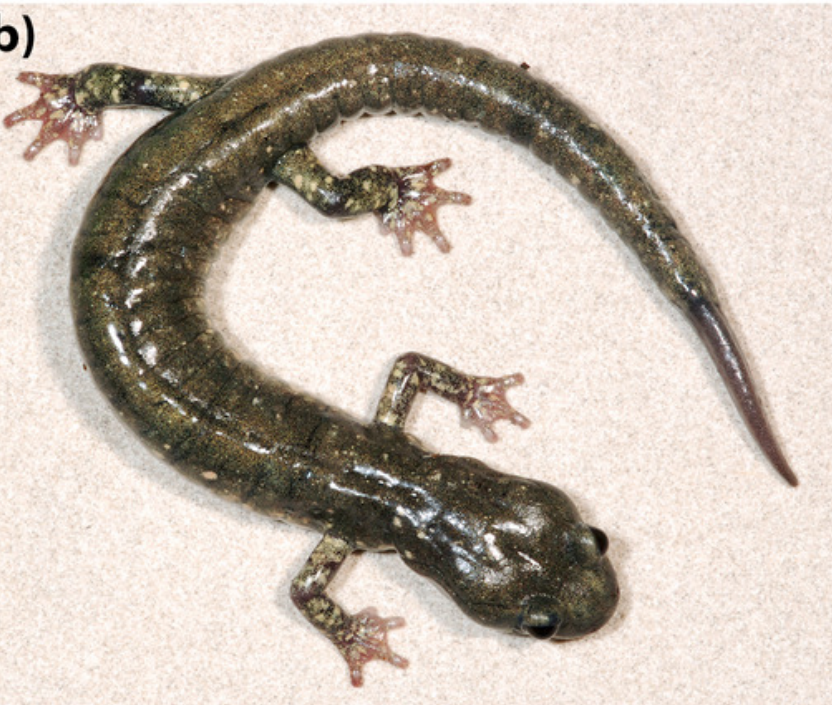

(c)

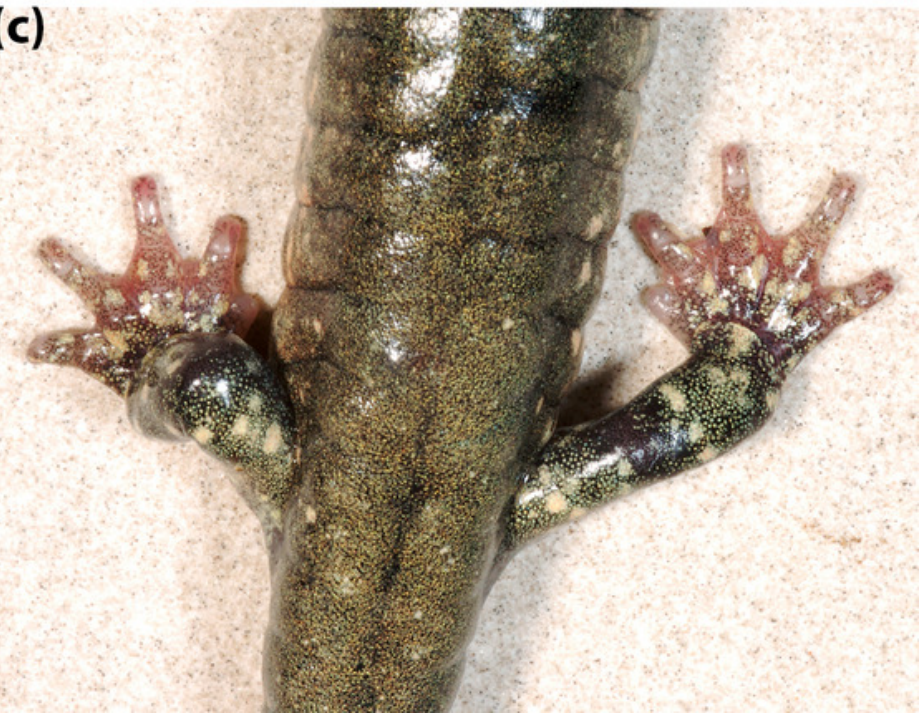


Peer

Manuscript to be reviewed

Figure 7

An ontogenetic series of seven Aneides klamathensis from ca. 4 km. NW Salver, Trinity Co., CA.

The black and white photograph of living, anaesthetized specimens shows the gradual increase in size and number of whitish pigment cells with size, and the relatively sparse number of such cells in this taxon (specimens arranged by J. F. Lynch and later preserved in MVZ; photo: Alfred Blaker, UC Berkeley Scientific Photographic Laboratory).

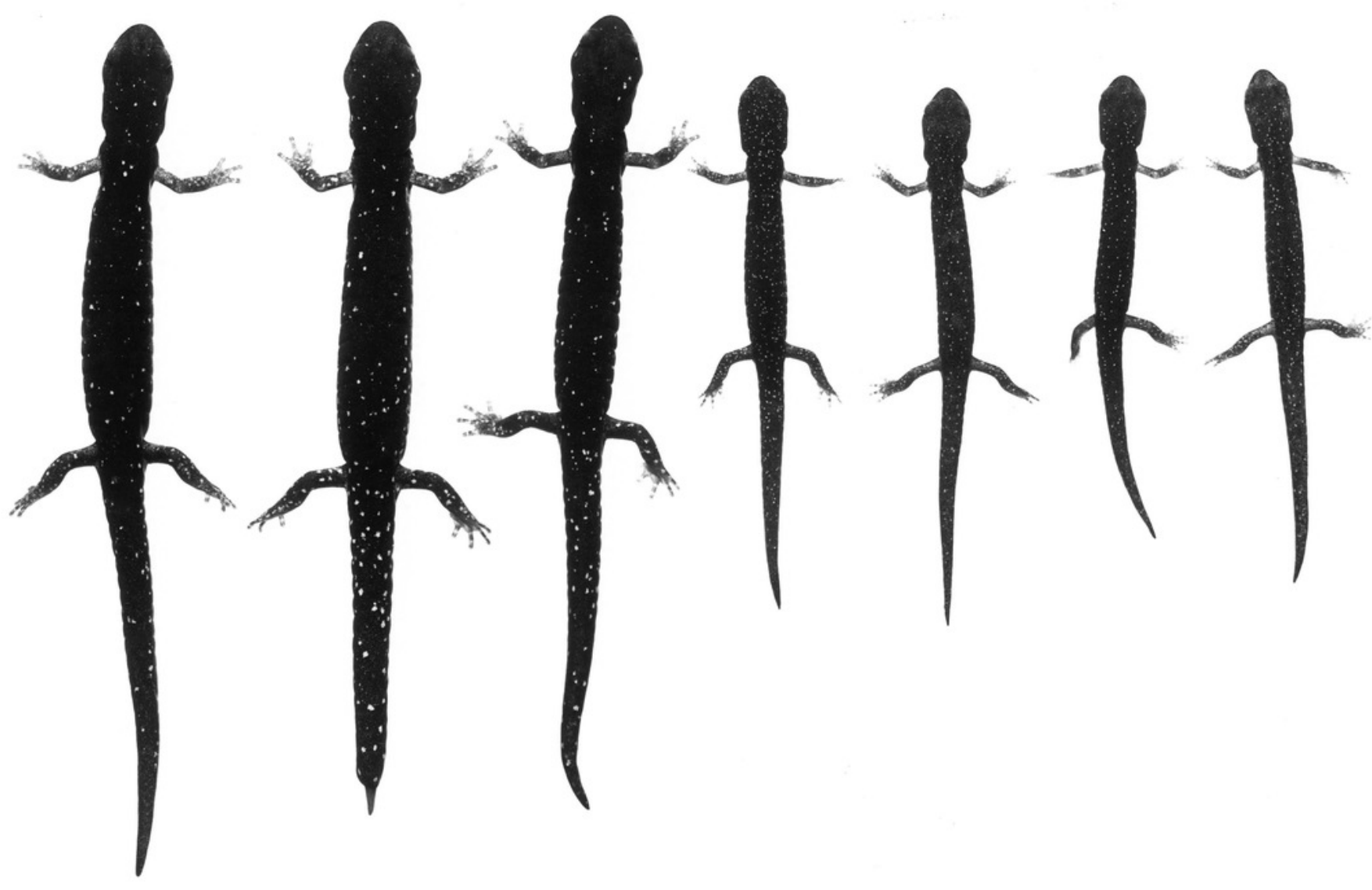

Peer) reviewing PDF | (2019:04:36410:1:1:NEW 22 Jun 2019) 
Figure 8 (on next page)

Phylogenetic relationships of the Aneides flavipunctatus complex.

(a) BEAST analysis of the ND4, cytb, and 125 mitochondrial genes, (b) *BEAST analysis of 13 nuclear loci, and (c) *BEAST analysis of three mtDNA and 13 nDNA loci. Trees adapted from Reilly \& Wake (2015). 


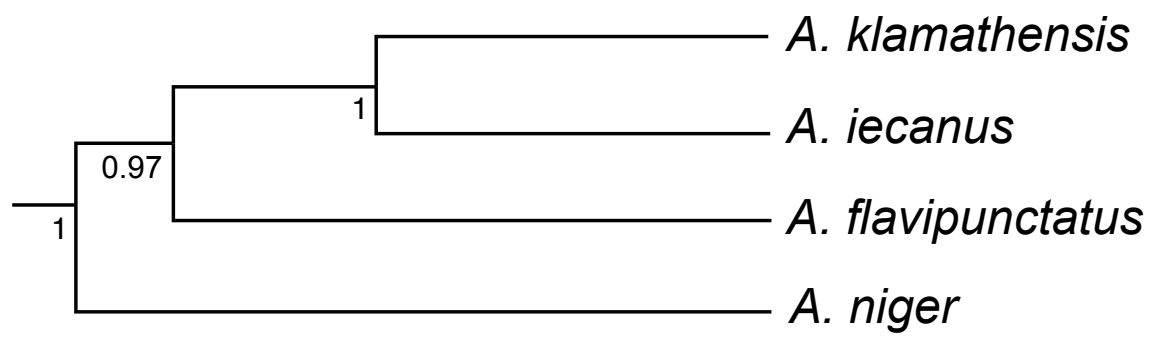

(b) nDNA (13 loci)

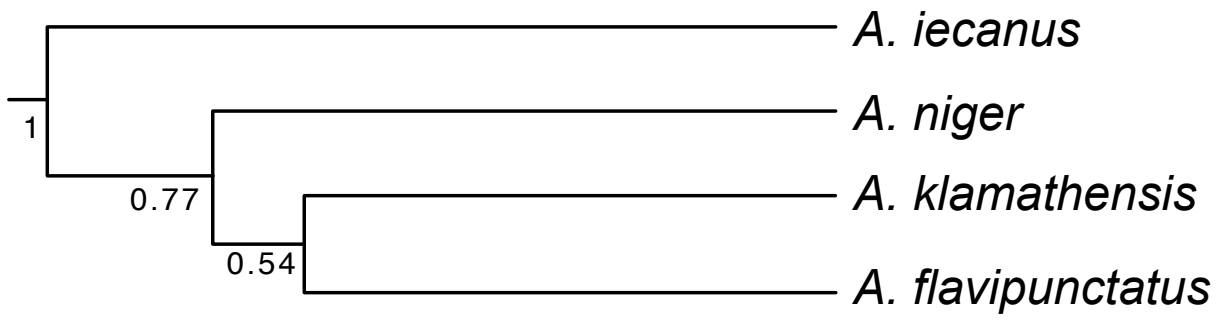

(c) $m t D N A+n D N A$

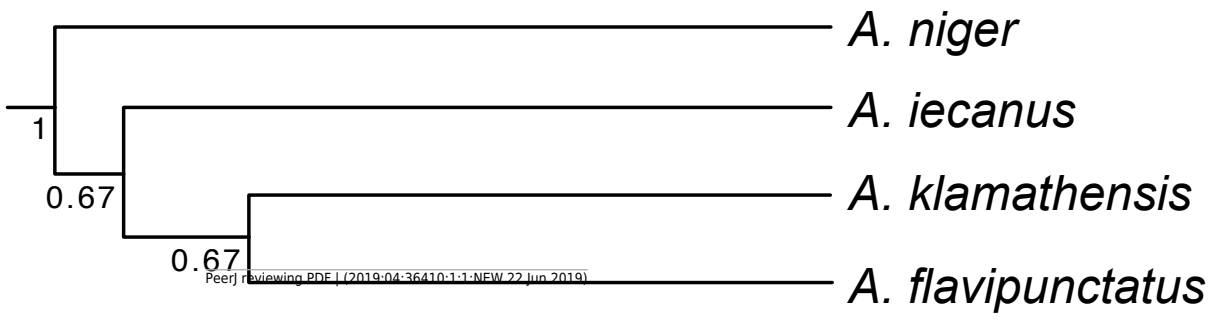




\section{Figure 9}

Aneides niger from the campus of UC Santa Cruz.

(a) An adult female exhibiting a pure black coloration, (b) an adult male with very small yellow flecks, (c) a juvenile which retains some xanthophore pigment frosting on the dorsal surface, and (d) a hatchling with bright blueish iridophore pigment flecks, xanthophore frosting and bright yellow color at the base of the limbs (common in all four species). All specimens released. (photos: M. Mulks)
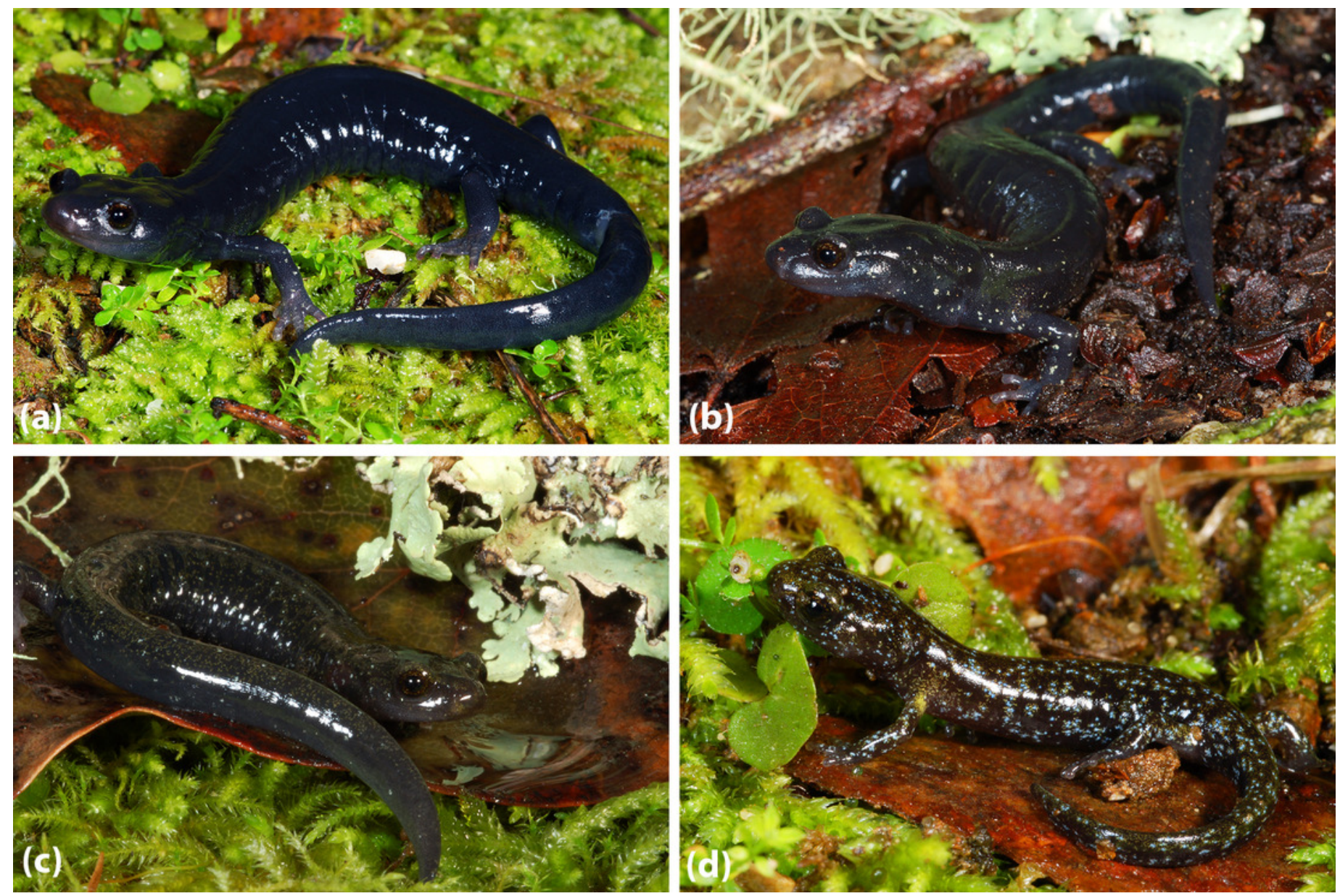


\section{Figure 10}

Adult Aneides iecanus.

Photographed in life near Dekkas Rock, east side of McCloud Arm, Lake Shasta, Shasta Co., CA $\left(40.871418^{\circ} \mathrm{N},-122.223491^{\circ} \mathrm{W}\right)$. Note dense scattering of moderately small whitish pigment cells. Specimen released (Photo: D. B. Wake).

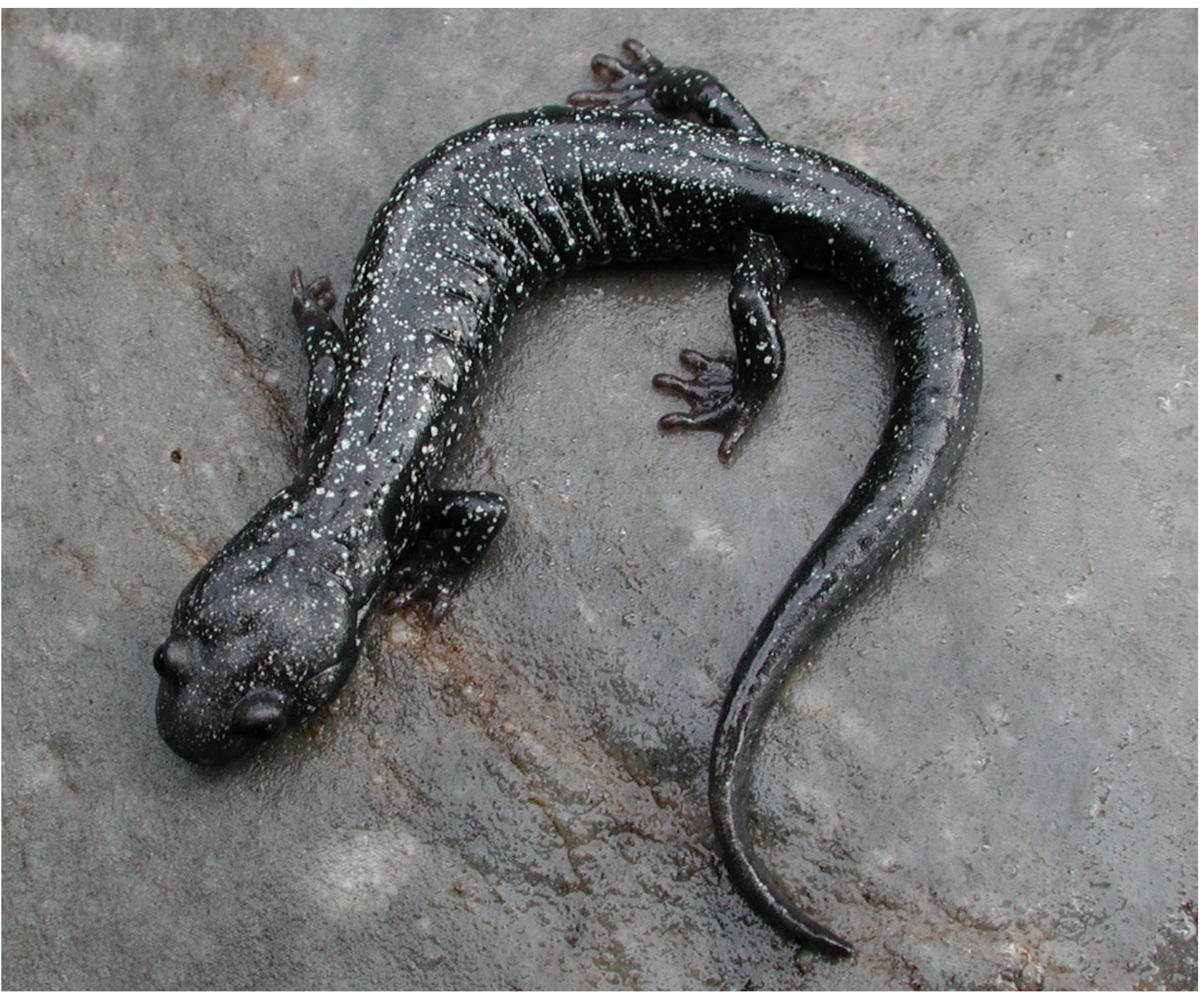


Peer

Manuscript to be reviewed

Figure 11

An ontogenetic series of ten Aneides iecanus from Castle Crags region, Shasta Co., CA.

The black and white photograph of living, anaesthetized specimens shows the gradual (but not monotonic) increase in size and number of whitish pigment cells with size, and the relatively dense number of such cells in adults of this taxon. Note the greatly enlarged jaw muscles of adults (specimens arranged by J. F. Lynch and later preserved in MVZ; photo: Alfred Blaker, UC Berkeley Scientific Photographic Laboratory).

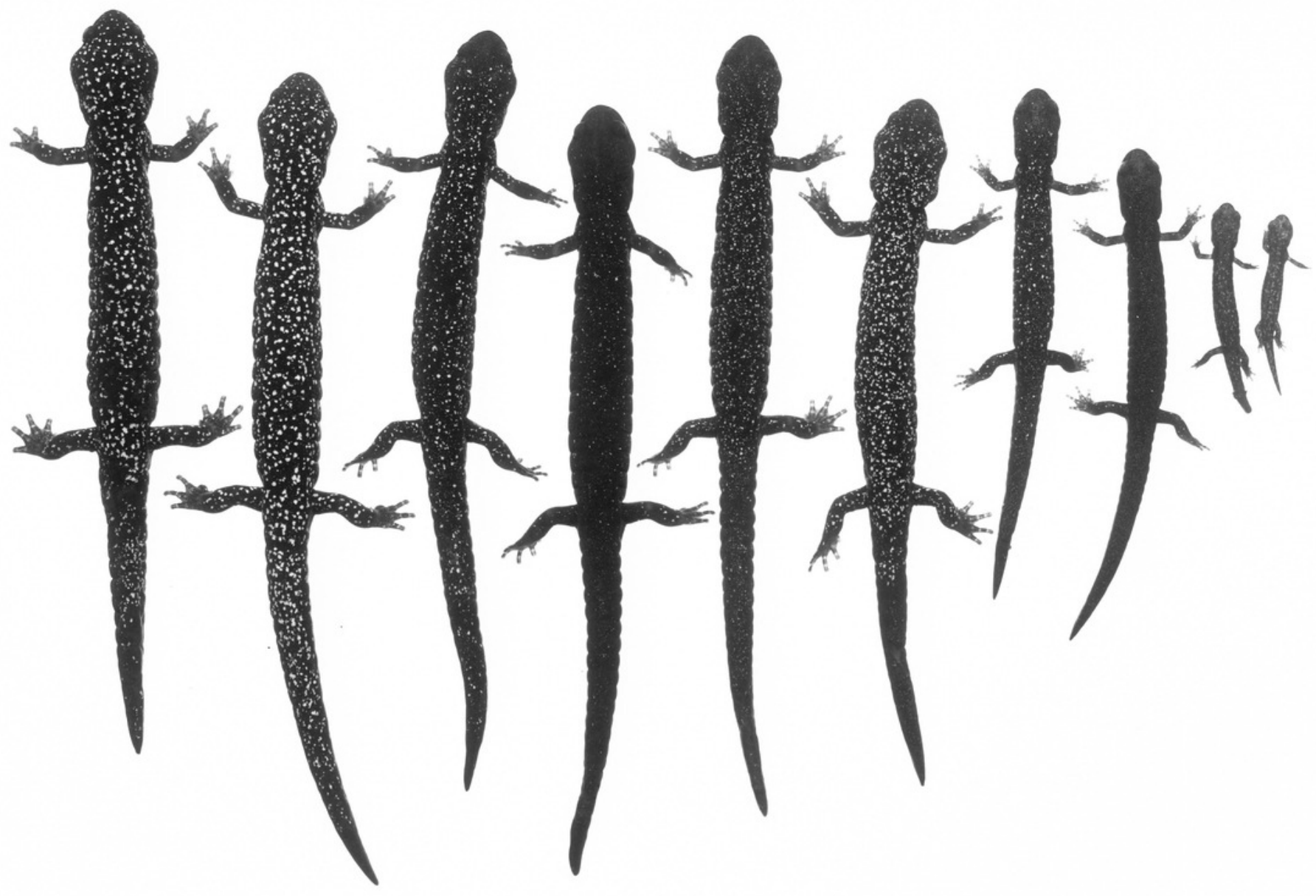

Peer reviewing PDF | (2019:04:36410:1:1:NEW 22 Jun 2019) 


\section{Figure 12}

A series of $A$. flavipunctatus exhibiting some of the more common color patterns.

(a) MVZ 264011 from 3 km W Miranda, Humboldt Co., CA, (b) MVZ 269402 from 6 km SE Scotia (locality \#14 from Fig. 2), Humboldt Co., CA, (c) MVZ 264056 from 7 km S Potter Valley, Mendocino Co., CA, (d) MVZ 269459 from 7 km E Geyserville, Sonoma Co., CA, (e) a female (found and released) from $\sim 10 \mathrm{~km}$ W Geyserville, Sonoma Co., CA, and (f) MVZ 264023 from $\sim 5$ km E Fort Bragg, Mendocino Co., CA. (Photos: (a)- A. Gottscho; (b, c, d, f)- S. Reilly; (e)- M. Mulks) 

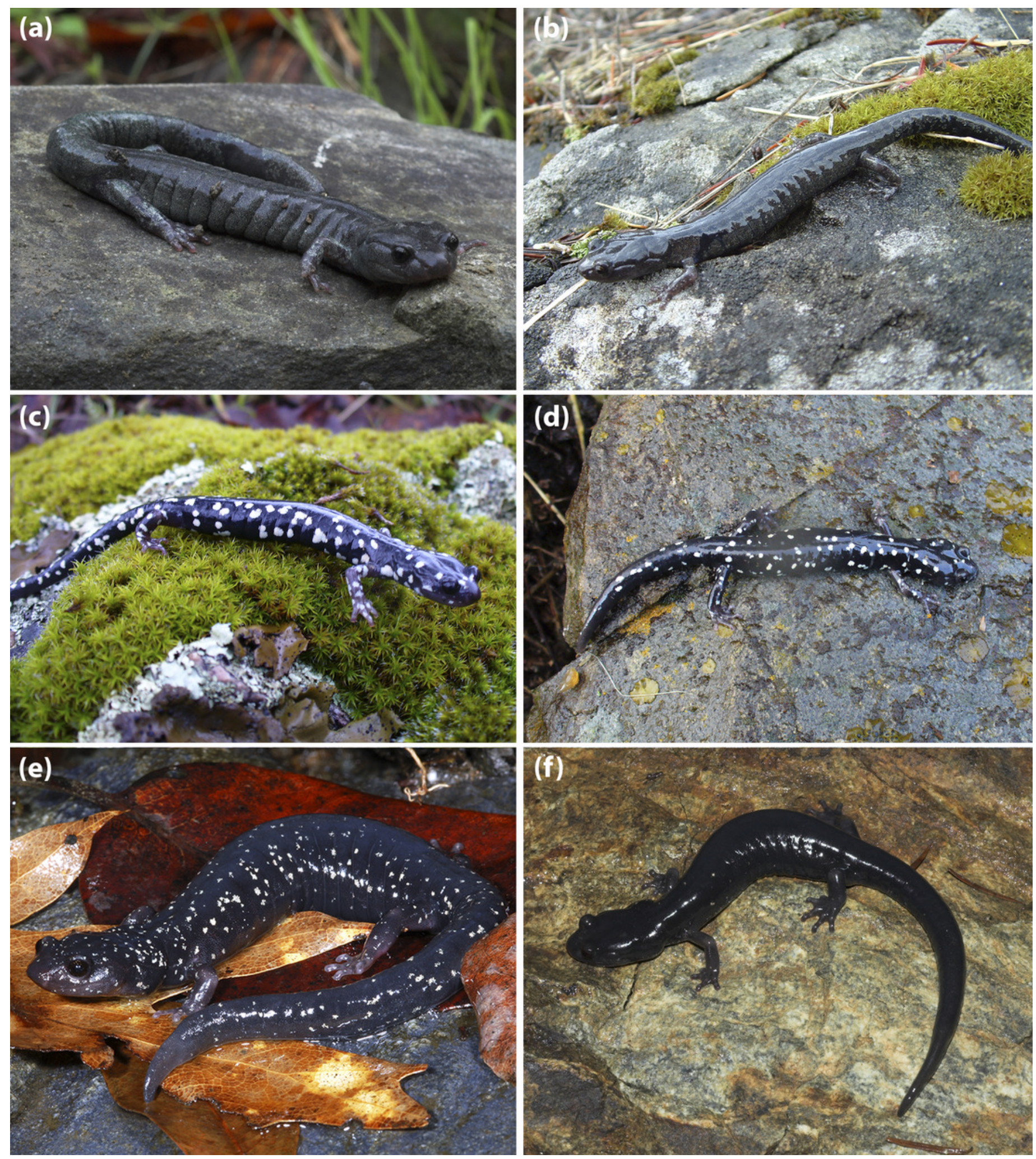


\section{Figure 13}

An ontogenetic series of ten Aneides flavipunctatus from area about $3.2 \mathrm{~km} \mathrm{E}, 0.5 \mathrm{~km} \mathrm{~S}$ Geyserville, Sonoma Co., CA.

The black and white photograph of living, anaesthetized specimens shows the relatively numerous and large whitish pigment cells with size, and the relatively dense concentration of such cells in adults of southern inland populations of this taxon (specimens arranged by J. F. Lynch and later preserved in MVZ; photo: Alfred Blaker, UC Berkeley Scientific Photographic Laboratory).

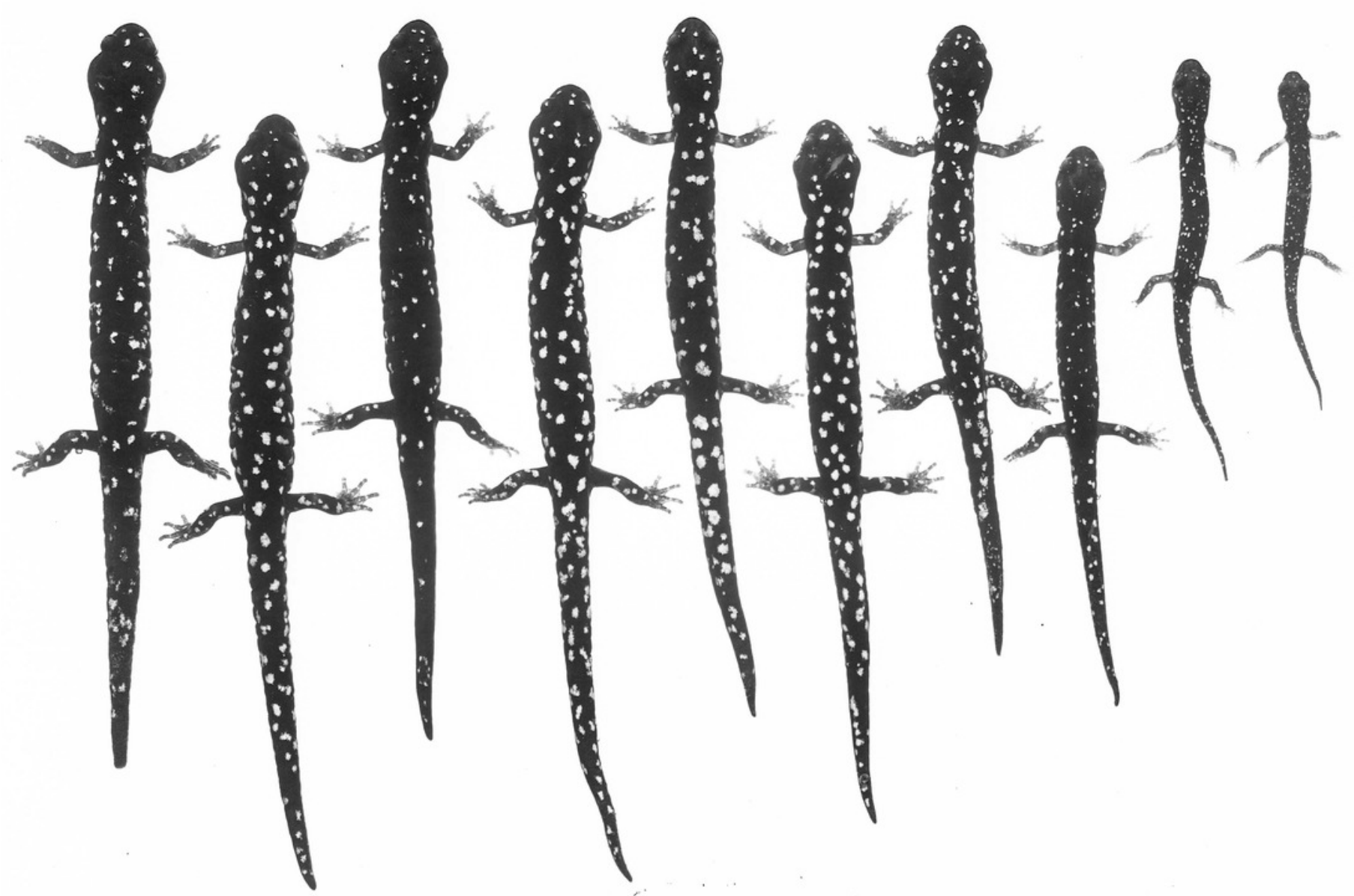




\section{Figure 14}

Lectotype and paralectotype of $A$. flavipunctatus.

(a) Photo of the lectotype of Plethodon flavipunctatus Strauch 1870, ZISP (Zoological Institute St. Petersburg) 156, courtesy of N. Ananyeva and K. Milto, Zoological Collections, Academy of Science, St. Petersburg, Russia. (b) Photo of the sole remaining paralectotype of Plethodon flavipunctatus Strauch 1870, ZISP 157, courtesy of N. Ananyeva and K. Milto, Zoological Collections, Academy of Science, St. Petersburg, Russia. 


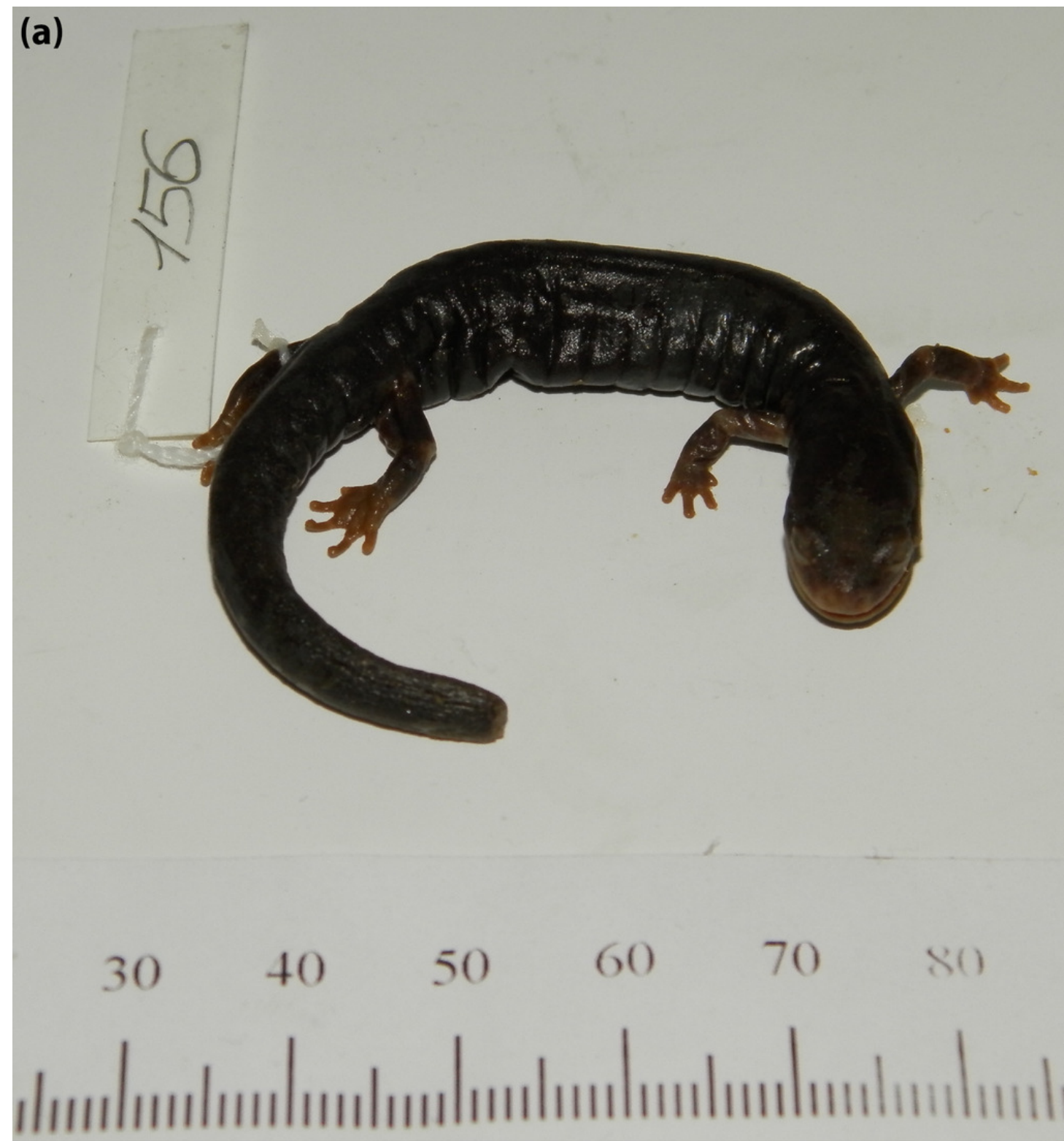

(b)

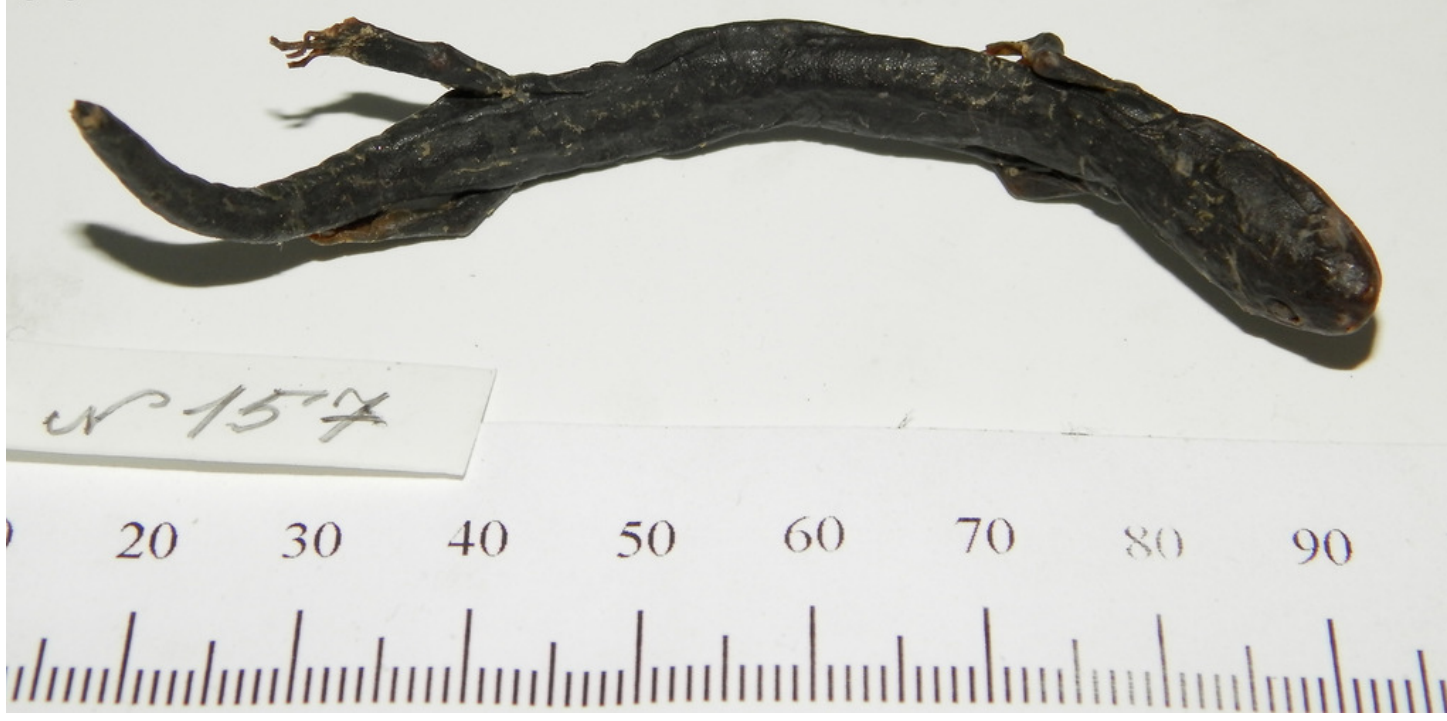




\section{Figure 15}

A series of $A$. flavipunctatus from the Longvale/Laytonville region of Mendocino Co., CA.

This area is identified as a contact zone between two genetically differentiated groups of populations (see Reilly et al. 2012; Reilly \& Wake 2015). (a) MVZ 264029 from 7 km S Laytonville, (b) MVZ 264032 from 16 km N Laytonville, (c) male (front) MVZ 264028 and female (behind) MVZ 264049 from Longvale, and (d) MVZ 264031 from 9 km N Laytonville. (photos: M. Mulks)
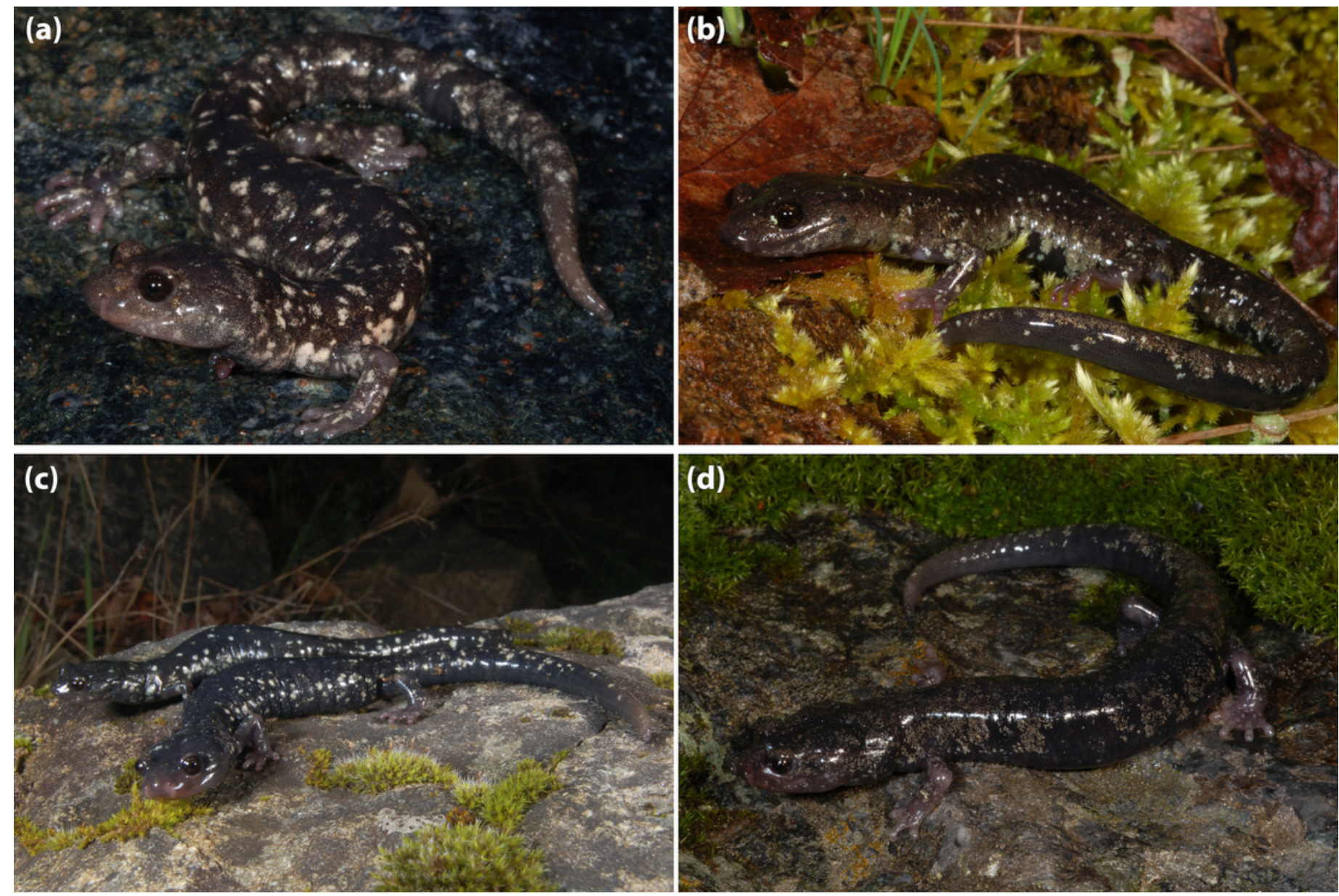